\section{Probing Nucleic Acid Structure with Shape-Selective Rhodium and Ruthenium Complexes}

This unit describes the use of transition metal complexes, specifically rhodium and ruthenium compounds, as photochemical probes of the structure of DNA and RNA. Such complexes have proven to provide a versatile platform for the design of chemical reagents to probe nucleic acid structure. The central transition metal ion provides both a rigid, substitutionally inert framework and an octahedral geometry for ligand coordination. The metal complexes can be constructed to define shapes, symmetries, and functionalities that complement those of the nucleic acid target. In addition, the rich photochemistry of rhodium and ruthenium allows easy identification of sites of complex binding by lightinduced nucleic acid cleavage. The modular construction of such complexes, allowing use of a variety of commercially available or custom-synthesized ligands, makes it possible to generate many different probes to examine various subtle and not-so-subtle characteristics of nucleic acids.

In the procedures that are described, end-labeled DNA or RNA is incubated with a single transition metal reagent and then irradiated with visible or ultraviolet light to promote cleavage of the nucleic acid polymer strand. The resulting cleavage products are then observed by polyacrylamide gel electrophoresis (PAGE). These common procedures are used with different metal complexes to probe various characteristics of nucleic acid systems. For rhodium compounds, strand cleavage is affected by direct metal complex photochemistry; for ruthenium compounds, cleavage is induced by singlet oxygen-induced damage followed by treatment with piperidine. Metal complexes of varied structure are utilized to explore different characteristics of the nucleic acids. Depending on the binding mode and specificity of the complexes, it is possible to explore characteristics such as groove width and depth (see Basic Protocol 1), the presence of unusual structures like cruciforms or Z DNA (see Basic Protocol 2), mismatches or abasic sites (see Basic Protocol 3), and tertiary folding of nucleic acids (see Basic Protocol 5). In addition, such complexes can be used as photofootprinting agents to study other molecules binding to nucleic acids (see Basic Protocol 4) and as singlet oxygen sensitizers for specific reaction with guanine bases in DNA or RNA (see Basic Protocol 6). Inorganic syntheses of the required metal complexes are included for each procedure (see Support Protocols 1 to 6). General guidelines for preparing labeled nucleic acids, for photolysis, and for mapping cleavage sites are also presented (see Support Protocols 7 to 9).

CAUTION: The procedures described in this unit utilize strong acids, flammable liquids, glassware under vacuum, and cryogens. All reagents should be used with care, using appropriate personal and laboratory safety equipment, and in well-ventilated fume hoods. The syntheses of the transition metal reagents involve polycyclic aromatic compounds, most of which are either suspected or known carcinogens. All precautions recommended by suppliers should be taken in order to prevent undue exposure to dusts or solutions. The metal complexes made in these protocols bind to nucleic acids with high affinity and promote strand cleavage upon exposure to light. As a result, they should be handled with care and contact with them should be avoided. The light sources used in DNA photocleavage experiments produce high-intensity ultraviolet light. Focused light beams can cause skin burns and severe eye damage. The radioactivity used in nucleic acid labeling procedures must be used in compliance with all appropriate regulations and guidelines. When performing electrophoresis portions of the protocols, it must be remembered that unpolymerized acrylamide is a potent, cumulative neurotoxin and all contact with it must

Contributed by Brian A. Jackson and Jacqueline K. Barton

Current Protocols in Nucleic Acid Chemistry (2000) 6.2.1-6.2.39

Copyright $(2000$ by John Wiley \& Sons, Inc.
UNIT 6.2

Chemical and Enzymatic Probes for Nucleic Acid Structure 
be avoided. In all cases, the waste products produced by these syntheses and biochemical experiments should be disposed of according to good laboratory practices.

BASIC PROTOCOL 1
Probing Nucleic Acid Structure

\section{MAPPING DNA MAJOR AND MINOR GROOVE CHARACTERISTICS}

Two metal complexes of differing structural characteristics, bis $(1,10$-phenanthroline $)\left(9,10\right.$-phenanthrenequinone diimine)rhodium(III), $\left[\mathrm{Rh}(\mathrm{phen})_{2}(\mathrm{phi})\right]^{3+}$, and tris(3,4,7,8-tetramethyl-1,10-phenanthroline)ruthenium(II), $\left[\mathrm{Ru}(\mathrm{TMP})_{3}\right]^{2+}$, can be used to examine variations in structure and local conformation in stretches of putatively B-form DNA. For reference, the structures of the complexes are included as Figure 6.2.1. The two coordination compounds bind to DNA by different modes and, as a result, recognize different structural characteristics of the nucleic acid. $\left[\mathrm{Rh}(\mathrm{phen})_{2}(\mathrm{phi})\right]^{3+}$ binds in the major groove by intercalation of its phi ligand, and thus recognizes sites on the DNA where the geometry of the double helix can accommodate its bulky phenanthroline ligands. Upon irradiation with UV light, it directly cleaves the DNA at its site of binding. Conversely, $\left[\mathrm{Ru}(\mathrm{TMP})_{3}\right]^{2+}$ binds to the surface of the DNA minor groove and shows a preference for A-form helices. The ruthenium complex cleaves DNA by sensitizing singlet oxygen upon irradiation. When taken together, DNA cleavage patterns generated by both of these complexes serve as a straightforward method to map out the geometrical characteristics of a long DNA sequence.

For the mapping of an isolated DNA sequence, end-labeled DNA is incubated with each metal complex and photolysed to promote strand cleavage. Because $\left[\mathrm{Rh}(\mathrm{phen})_{2}(\mathrm{phi})\right]^{3+}$ directly cleaves the DNA, no subsequent treatment of those samples is required before electrophoresis. For $\left[\mathrm{Ru}(\mathrm{TMP})_{3}\right]^{2+}$, samples must be subsequently treated with hot piperidine to convert the singlet oxygen damage to strand breaks. In addition, due to the diffusable nature of the singlet oxygen, $\left[\mathrm{Ru}(\mathrm{TMP})_{3}\right]^{2+}$ cleavage must also be compared with cleavage by $\left[\mathrm{Ru}(\mathrm{phen})_{3}\right]^{2+}$, which binds nonspecifically to DNA. The difference between the cleavage patterns of the two complexes reveals the sequence-specific recognition effect.

Specific details for these rhodium and ruthenium photolysis reactions are given in this protocol. A more general yet thorough discussion of photolysis is given in Support Protocol 8, which should be consulted before carrying out this procedure.

\section{Materials}

Labeled DNA solution (see Support Protocol 7): for cleavage with $\left[\mathrm{Rh}(\mathrm{phen})_{2}(\mathrm{phi})\right]^{3+}$, typically $100 \mu \mathrm{M}$ base pairs in $2 \times$ buffer for cleavage with $\left[\mathrm{Ru}(\mathrm{TMP})_{3}\right]^{2+}$ or $\left[\mathrm{Ru}(\mathrm{TMP})_{3}\right]^{2+}$, typically $200 \mu \mathrm{M}$ base pairs in $2 \times$ Tris/ $\mathrm{NaCl} /$ imidazole buffer (see recipe)
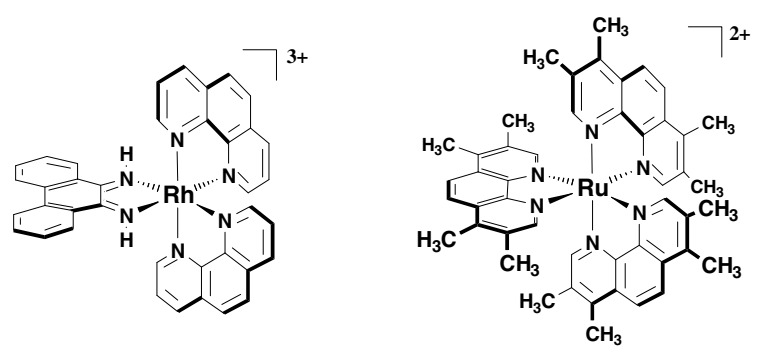

Figure 6.2.1 $\left[\mathrm{Rh}(\text { phen })_{2}(\mathrm{phi})\right]^{3+}$ and $\left[\mathrm{Ru}(\mathrm{TMP})_{3}\right]^{2+}$. 
Metal complex solution (see recipe for preparation of stock solutions):

rac- or $\Delta$-[Rh(phen) $)_{2}(\text { phi) }]^{3+}$ (typically $10 \mu \mathrm{M}$; see Support Protocol 1 for synthesis; see Support Protocol 2 for separation of enantiomers)

rac-[Ru(TMP) $\left.]_{3}\right]^{2+}$ (typically $60 \mu \mathrm{M}$; see Support Protocol 3)

rac- $\left[\mathrm{Ru}(\text { phen })_{3}\right]^{2+}$ (typically $60 \mu \mathrm{M}$; see Support Protocol 3)

$1 \mathrm{M}(10 \% \mathrm{v} / \mathrm{v})$ piperidine solution in deionized water

Dry ice

Heating block or bath set to $90^{\circ} \mathrm{C}$

Speedvac (Savant) or lyophilizer

Additional reagents and equipment for photolysing metal complexes (see Support

Protocol 8) and mapping cleavage sites (see Support Protocol 9)

\section{Cleave DNA with $[\text { Rh(phen })_{2}($ phi $\left.)\right]^{3+}$}

1. Photolyse DNA/metal complexes as described (see Support Protocol 8, steps 1 to 4), mixing equal volumes of labeled DNA solution and rac- or $\Delta-\left[\mathrm{Rh}(\mathrm{phen})_{2}(\mathrm{phi})\right]^{3+}$ metal complex solution for a total volume of 10 to $50 \mu \mathrm{L}$. Include dark and light controls for each DNA of interest. Irradiate either 1 to $5 \mathrm{~min}$ at $313 \mathrm{~nm}$ or 5 to 20 $\min$ at $365 \mathrm{~nm}$.

It is best to separate the enantiomers and use only the $\Delta$ enantiomer because it has better DNA-binding characteristics. If both are used, separate dark controls are required to ensure that one of the two enantiomers has not become contaminated in any way.

The choice of irradiation paradigm is dependent on the light source available. The small differences in the results obtained at these two wavelengths are not relevant for these structure determinations.

2. Dry samples in a Speedvac evaporator or precipitate samples as described (see Support Protocol 8, steps 5 to 7).

3. Count samples and add loading buffer (see Support Protocol 8, step 8).

4. Map cleavage sites as described (see Support Protocol 9). Identify the specific bases of cleavage by comparing to Maxam-Gilbert sequencing reactions as described.

Sites of $\left[R h(p h e n)_{2}(p h i)\right]^{3+}$ binding are indicated by cleavage bands in the experimental lanes. Although cleavage band intensity is related to the affinity of the complex for individual DNA sites, possible differences in photocleavage efficiency from site to site make direct comparisons difficult.

\section{Cleave DNA with $\left[\mathrm{Ru}(\mathrm{TMP})_{3}\right]^{2+}$ and $\left[\mathrm{Ru}(\text { phen })_{3}\right]^{2+}$}

5. Photolyse parallel samples using both $\mathrm{rac}-\left[\mathrm{Ru}(\mathrm{TMP})_{3}\right]^{2+}$ and rac- $\left[\mathrm{Ru}(\mathrm{phen})_{3}\right]^{2+}$ complexes as described (see Support Protocol 8, steps 1 to 4), mixing equal volumes of metal complex solution and labeled DNA solution for a total volume of 10 to $50 \mu \mathrm{L}$. Include dark and light controls for each DNA and for each metal complex. Irradiate 20 to $40 \mathrm{~min}$ at $442 \mathrm{~nm}$.

Imidazole is used in DNA solutions for these reactions to help solubilize the ruthenium probe, which is extremely hydrophobic.

The metal complex stock solutions prepared for this experiment can be close to saturation and may require a small amount of a co-solvent, such as ethanol, to keep the complexes in solution. Complex precipitation can be a source of experimental error and irreproducibility.

6. Dry samples in a Speedvac evaporator or precipitate samples as described (see Support Protocol 8, steps 5 to 7). 
SUPPORT PROTOCOL 1

Probing Nucleic Acid Structure
7. Add $100 \mu \mathrm{L}$ of piperidine solution to each of the dried samples and heat $30 \mathrm{~min}$ at $90^{\circ} \mathrm{C}$.

Treatment with hot piperidine causes strand scission at the sites of singlet oxygen damage on the DNA bases.

CAUTION: Piperidine is a highly toxic liquid of high vapor pressure and is readily absorbed through the skin. Contact should be avoided and, if possible, manipulations should be made in a fume hood.

8. Freeze samples on dry ice and lyophilize off the piperidine solution.

9. Count samples and add loading buffer (see Support Protocol 8, step 8).

10. Map cleavage sites as described (see Support Protocol 9).

11. Subtract histograms of $\left[\operatorname{Ru}(\mathrm{TMP})_{3}\right]^{2+}$ and $\left[\mathrm{Ru}(\mathrm{phen})_{3}\right]^{2+}$ cleavage patterns to remove the guanine bias associated with singlet oxygen reactivity. Identify the specific bases of cleavage by comparison to Maxam-Gilbert sequencing reactions as described in Support Protocol 9.

Cleavage by $\left[R u(p h e n)_{3}\right]^{2+}$ is the same at all guanine residues due to its nonspecific binding behavior. Cleavage by the methylated complex is nonuniform as a result of preferential binding at individual sites. Cleavage by $\left[R u(T M P)_{3}\right]^{2+}$ is also observed at nonguanine residues near its binding sites. The difference between the cleavage patterns shows characteristic "bell-shaped" cleavage distributions as a result of high local concentrations of the diffusing singlet oxygen near the sites of $\left[R u(T M P)_{3}\right]^{2+}$ binding.

\section{SYNTHESIS OF BIS(1,10-PHENANTHROLINE)} (9,10-PHENANTHRENEQUINONE DIIMINE)RHODIUM(III) TRICHLORIDE

Although several syntheses of $\left[\mathrm{Rh}(\mathrm{phen})_{2}(\mathrm{phi})\right]^{3+}$ have been reported, the most reliable and highest-yielding procedure involves a three-step process. The synthetic scheme is summarized in Figure 6.2.2. In this preparation, the two ancillary phenanthroline ligands are added to the complex first (modified from Gillard et al., 1965). The resulting singly charged $\left[\mathrm{Rh}(\text { phen })_{2}(\mathrm{Cl})_{2}\right]^{1+}$ is then converted to $\left[\mathrm{Rh}(\mathrm{phen})_{2}\left(\mathrm{NH}_{3}\right)_{2}\right]^{3+}$ by treatment with

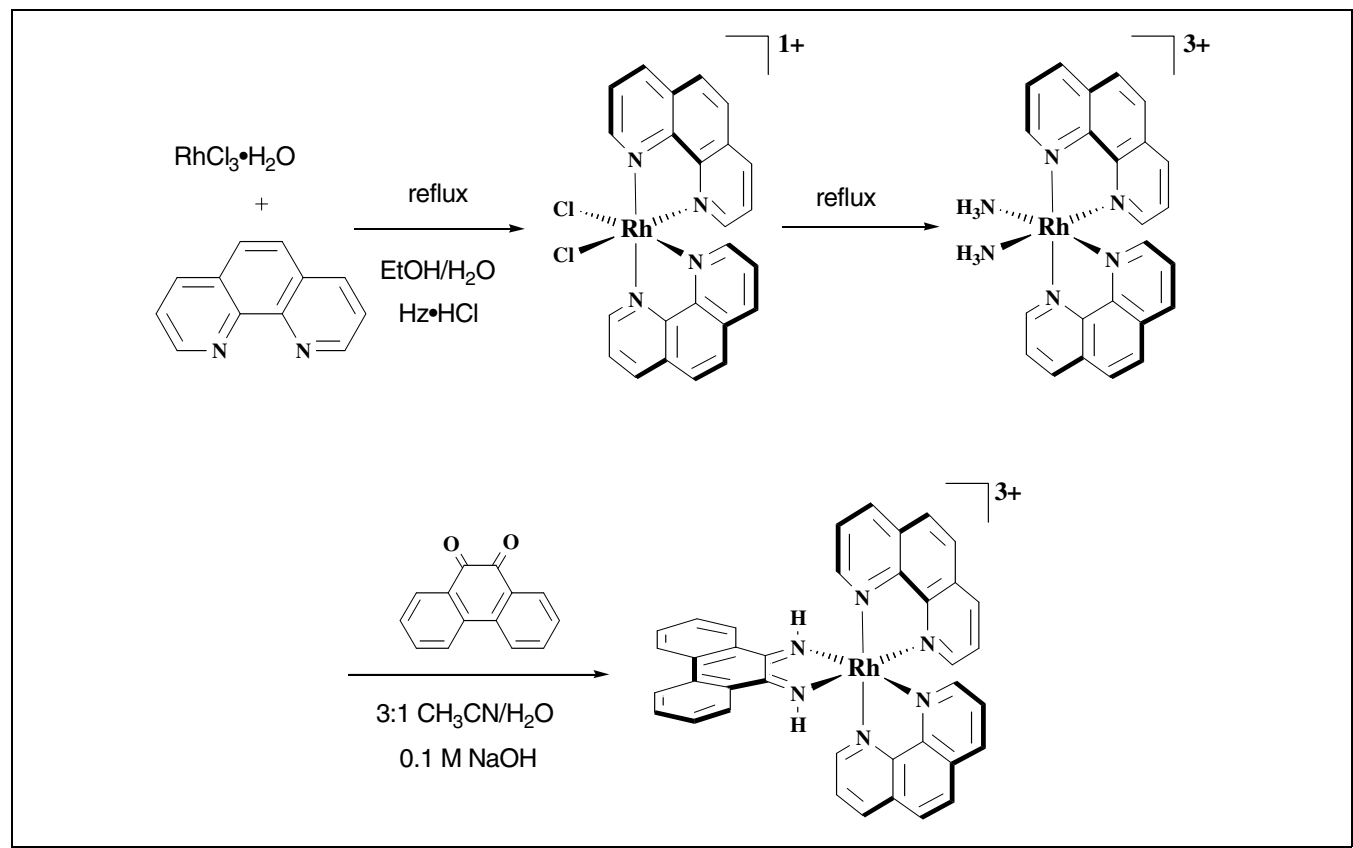

Figure 6.2.2 Synthesis of $\left[\mathrm{Rh}(\mathrm{phen})_{2}(\mathrm{phi})\right]^{3+} . \mathrm{Hz} \cdot \mathrm{HCl}$, hydrazine monohydrochloride. 
ammonium hydroxide (modified from Gidney et al., 1972). The bis-ammine complex is subsequently condensed with phenanthrene quinone to form the 9,10-phenanthrenequinone diimine (phi) intercalating ligand (modified from Mürner et al., 1998). All steps are carried out under ambient atmosphere and few extra precautions must be taken. Further details on the synthesis are available in Mürner et al. (1998).

\section{Materials}

Rhodium trichloride monohydrate

1,10-Phenanthroline

Hydrazine monohydrochloride

$95 \%(\mathrm{v} / \mathrm{v})$ ethanol, denatured

Concentrated (28\% to $30 \%$ ) ammonium hydroxide solution

Phenanthrene quinone

$3: 1(\mathrm{v} / \mathrm{v})$ acetonitrile (reagent grade or better)/0.4 M NaOH solution in distilled water

$1 \mathrm{M} \mathrm{HCl}$ solution (APPENDIX 2A)

Sephadex SP-C25 cation-exchange resin

$1 \mathrm{M} \mathrm{MgCl}_{2}$ solution (APPENDIX 2A) in distilled water

HPLC-grade acetonitrile

$0.1 \%(\mathrm{v} / \mathrm{v})$ trifluoroacetic acid (TFA) in distilled water (for Sep-Pak elution) and in deionized, filtered water (for HPLC)

\section{Reflux condenser}

Temperature-controlled magnetic stir plate

Oil bath or heating mantle

50- and $100-\mathrm{mL}$ round-bottom flasks

60-mL medium-frit glass funnel

250-mL filter flasks

Filter adapter

Aspirator or vacuum pump

Rotary evaporator

Chromatography column: 1 to 2 feet (30 to $61 \mathrm{~cm})$ long, 1 to 1.5 in. $(2.5$ to $3.8 \mathrm{~cm})$ diameter

500-mL Erlenmeyer flasks

Waters Sep-Pak 5-g C18 cartridges

15 -mL plastic centrifuge tube or 25 - to $50-\mathrm{mL}$ round-bottom flask

Lyophilizer (optional)

High-pressure liquid chromatography (HPLC) system with C18 reversed-phase column

Additional reagents and equipment for proton nuclear magnetic resonance $\left({ }^{1} \mathrm{H}\right.$ NMR), UV/visible spectrometry, and mass spectrometry

\section{Prepare $\left[\mathrm{Rh}(\text { phen })_{2}(\mathrm{Cl})_{2}\right] \mathrm{Cl}$}

1. Set up a reflux condenser with a temperature-controlled magnetic stir plate, an oil bath or heating mantle, and a $100-\mathrm{mL}$ round-bottom flask containing a stir bar.

2. Combine $1 \mathrm{~g}$ rhodium trichloride monohydrate and $1.6 \mathrm{~g}$ of 1,10-phenanthroline (2 eq) in the $100-\mathrm{mL}$ round-bottom flask.

3. Add $25 \mathrm{mg}$ hydrazine monohydrochloride and $75 \mathrm{~mL}$ of a $1: 1(\mathrm{v} / \mathrm{v})$ mixture of water and $95 \%$ ethanol.

Chemical and Enzymatic Probes for Nucleic Acid Structure 
4. Stir and bring the mixture to reflux. Continue refluxing until all material has gone into solution and the color has changed from violet to yellow ( $\sim 4$ to $6 \mathrm{hr}$ ).

Hydrazine monohydrochloride acts as a reductive catalyst. By reducing the Rh(III) to $R h(I I)$, ligand substitution is facilitated.

5. Remove residual unreacted ligand by filtering the hot solution through a $60-\mathrm{mL}$ medium-frit glass funnel using an aspirator or a vacuum pump. Discard the ligand and collect filtrate in a $250-\mathrm{mL}$ filter flask.

6. Refrigerate the filtrate overnight.

The product will precipitate as yellow, powdery crystals.

The solubility of the singly charged dichloro product in water is quite low. Any traces of $\left[R h(p h e n)_{3}\right]^{3+}$ that are formed in the course of the reaction remain in solution and are eliminated by filtration.

7. Save the crystal product by filtration as in step 5. Collect the mother liquor in a $250-\mathrm{mL}$ filter flask and store at $4^{\circ} \mathrm{C}$ in case it is needed to form a second crop of crystals.

8. Dry the first crop of product under vacuum in a sealed flask, using an aspirator or vacuum pump.

Typical yields for the first crop are in the range of $60 \%$.

9. Characterize the product by ${ }^{1} \mathrm{H}$ NMR and mass spectrometry.

Spectroscopic data are included below (see Compound Characterization).

Prepare $\left[\mathrm{Rh}(\text { phen })_{2}\left(\mathrm{NH}_{3}\right)_{2}\right] \mathrm{Cl}_{3}$

10. Combine 0.5 to $1.0 \mathrm{~g}\left[\mathrm{Rh}(\mathrm{phen})_{2}\left(\mathrm{Cl}_{2}\right)\right] \mathrm{Cl}$ and 30 to $50 \mathrm{~mL}$ concentrated ammonium hydroxide solution in a $100-\mathrm{mL}$ round-bottom flask.

11. With rapid stirring, bring the solution to reflux. Continue heating until all the yellow solid has dissolved ( $\sim 15$ to $30 \mathrm{~min}$ ). Remove the reaction from the heat and allow to cool.

As the complex is converted from the singly charged dichloride to the triply charged diammine, solubility in ammonium hydroxide increases. As a result, solubility can serve as a rough measure of the reaction's progress.

12. Remove the solvent from the reaction mixture using a rotary evaporator with a vacuum pump.

The diammine product, which appears as a translucent yellow scale in the flask, is typically recovered in $90 \%$ to $100 \%$ yield.

13. Characterize the product by ${ }^{1} \mathrm{H}$ NMR, UV/visible spectrometry, and mass spectrometry.

Spectroscopic data are included below (see Compound Characterization).

Prepare $\left[R h(p h e n)_{2}(p h i)\right] C l_{3}$

14. Combine $50 \mathrm{mg}\left[\mathrm{Rh}(\mathrm{phen})_{2}\left(\mathrm{NH}_{3}\right)_{2}\right] \mathrm{Cl}_{3}$ and $25 \mathrm{mg}$ phenanthrene quinone (an excess) in a $50-\mathrm{mL}$ round-bottom flask.

15. Add 30 to $40 \mathrm{~mL}$ of $3: 1$ acetonitrile/0.4 $\mathrm{M} \mathrm{NaOH}$ solution and stir briskly.

Probing Nucleic Acid Structure

Sometimes the two solvent components initially form immiscible layers, but with rapid stirring there is sufficient mixing for the reaction to progress. 
16. Stir at room temperature for 6 to $12 \mathrm{hr}$.

During this time the solution will go from yellow to a deep orange.

The reaction progresses by base deprotonation of the coordinated ammine ligands, which add to the quinone with subsequent loss of water. Although extreme precautions are not necessary, it is recommended that the reaction flask be covered with aluminum foil to avoid unnecessary exposure to light.

17. Stop the reaction by neutralizing the $\mathrm{NaOH}$ with an equimolar amount of $1 \mathrm{M} \mathrm{HCl}$ solution.

\section{Purify by cation exchange}

18. Swell 10 to $25 \mathrm{~g}$ dry Sephadex SP-C25 resin with 100 to $200 \mathrm{~mL}$ of $0.05 \mathrm{M} \mathrm{MgCl}_{2}$ solution for $\sim 15 \mathrm{~min}$.

The resin should swell completely but not consume all the free $\mathrm{MgCl}_{2}$ solution. A volume of extra solution ( 1 cm above the level of the swelled resin) is necessary for proper pouring of the column. If all the solution is consumed, more should be added to the mixture.

19. Swirl the slurry and prepare a cation-exchange column by pouring the slurry into a 1- to 2-foot-long chromatography column and allowing it to settle as the excess solvent flows through. Stop the flow from the bottom of the column when the $\mathrm{MgCl}_{2}$ solution level reaches the top of the packed column resin.

For adequate purification, the column should be $\geq 6$ inches $(\sim 15 \mathrm{~cm})$ high.

20. Dilute the reaction mixture into a large volume (300 to $400 \mathrm{~mL})$ of distilled water. Add the solution slowly to the top of the column, taking care not to unduly disturb the resin surface.

The metal complex will adhere to the resin at the very top of the packed column. Unreacted quinone will flow through immediately.

21. Elute metal complexes with increasing concentrations of $\mathrm{MgCl}_{2}$. Begin with 2 to 3 column vol of $0.05 \mathrm{M} \mathrm{MgCl}_{2}$ and increase steadily to $0.5 \mathrm{M}$. Collect all eluted bands in individual 500-mL Erlenmeyer flasks.

At the lowest concentrations, any additional unreacted quinone will elute off the column. This will be followed, as the concentration increases, by any unreacted diammine complex. The orange product band will elute between 0.2 and $0.5 \mathrm{M} \mathrm{MgCl}_{2}$.

22. For each column fraction containing $\left[\mathrm{Rh}(\mathrm{phen})_{2}(\mathrm{phi})\right] \mathrm{Cl}_{3}$, wash a Waters Sep-Pak 5-g C18 cartridge with 1 vol HPLC-grade acetonitrile followed by 1 vol water.

Isolation of the complex on the reversed-phase cartridge will remove excess $\mathrm{MgCl}$ from the desired product.

23. Load the product fractions onto the cartridges either by gravity or under suction. Allow the entire product fraction to be adsorbed onto the resin.

24. Wash with 2 to 3 vol distilled water.

25. Elute the desalted product band with $1: 1(\mathrm{v} / \mathrm{v})$ acetonitrile/0.1\% TFA. Collect the material in either a $15-\mathrm{mL}$ plastic centrifuge tube or a $25-$ to $50-\mathrm{mL}$ round-bottom flask, depending on which technique will be used to remove the solvent.

26. Isolate the metal complex from this solution by rotary evaporation or lyophilization.

The complex purified by cation-exchange chromatography has a purity $>95 \%$. Nonetheless, in the authors' laboratory it is customary to further purify the material by reversed-phase HPLC (RP-HPLC), as described below. If an HPLC apparatus is unavailable, other methods of verifying the purity of the metal complex can be used

Chemical and Enzymatic Probes for Nucleic Acid Structure 
(e.g., thin-layer chromatography using silica gel and 4:1:1:0.1 $\mathrm{M} \mathrm{CH}_{3} \mathrm{CN} /$ water/n-butanol/saturated $\mathrm{KNO}_{3}$ ).

Purify by RP-HPLC

27. Dissolve a small amount of the material (e.g., 1 to $2 \mathrm{mg}$ ) in a volume of water appropriate for the injection loop volume of the HPLC apparatus. Inject it onto a C18 reversed-phase HPLC column. Run a gradient from $0.1 \%$ TFA to a 1:1 (v/v) mixture of $0.1 \%$ TFA and acetonitrile over $30 \mathrm{~min}$.

The metal complex elutes between $20 \%$ and $30 \%$ acetonitrile.

28. Collect the product peak and evaporate or lyophilize the solvent.

29. Characterize the product by ${ }^{1} \mathrm{H}$ NMR, UV/visible spectrometry, and mass spectrometry.

Spectroscopic data are included below (see Compound Characterization).

SUPPORT PROTOCOL 2
Probing Nucleic Acid Structure

\section{SEPARATION OF ENANTIOMERS OF BIS(1,10-PHENANTHROLINE) (9,10-PHENANTHRNENEQUINONE DIIMINE)RHODIUM(III) TRICHLORIDE}

The rac- and $\Delta$-enantiomers of $\left[\mathrm{Rh}(\mathrm{phen})_{2}(\mathrm{phi})\right] \mathrm{Cl}_{3}$ are separated by ion-exchange chromatography with a chiral eluent. Typically, the procedure calls for a solution of cobalt L-cysteine sulfinate, $\mathrm{Co}(\mathrm{lcysu})_{3}$, which is made by procedures described by Dollimore and Gillard (1973) and presented in this protocol. Although procedures for both separating the enantiomers and making the cobalt complex are summarized here, the reader is directed to the original papers (Yoshikawa and Yamasaki, 1979; Cartwright et al., 1987) for more comprehensive details.

Alternatively, small amounts of the enantiomers of $\left[\mathrm{Rh}(\mathrm{phen})_{2}(\mathrm{phi})\right]^{3+}$ can be separated using a commercially available chiral HPLC column. Although chiral HPLC cannot produce the same amount of material as the chromatographic separation described here, it is useful for small-scale preparations or analysis of materials resolved by other means.

\section{Additional Materials (also see Support Protocol 1)}

Hexamminecobalt(III) chloride

Nitrogen or argon gas

L-Cysteine

Potassium hydroxide

$30 \%(\mathrm{v} / \mathrm{v})$ hydrogen peroxide

$\left[\mathrm{Rh}(\text { phen })_{2}(\right.$ phi) $] \mathrm{Cl}_{3}$ (see Support Protocol 1)

Sephadex CM-C25 ion-exchange resin

$0.1 \mathrm{M} \mathrm{KCl}$ solution in deionized water

Thermometer

500-mL, 2- or 3-neck round-bottom flasks with appropriate stoppers

Bubbler for nitrogen or argon gas, equipped with a long pipet

$\mathrm{pH}$ paper

60-mL coarse-frit glass funnels

500 -mL filter flasks

1000-mL Erlenmeyer flask

Chromatography columns:

2 to 4 feet $(61$ to $122 \mathrm{~cm})$ long, 1 to 1.5 in. $(2.5$ to $3.8 \mathrm{~cm})$ diameter

0.5 to 1 feet $(15$ to $30 \mathrm{~cm})$ long, 1 to 1.5 in. $(2.5$ to $3.8 \mathrm{~cm})$ diameter

Solvent bottles for reservoirs 
Recirculating column pump (optional)

Column end caps and tygon tubing for connecting recirculating pump and solvent reservoirs

Additional reagents and equipment for circular dichroism (CD) spectroscopy

\section{Prepare $\mathrm{K}\left[\mathrm{Co}(\text { lcysu })_{3}\right] \cdot 6 \mathrm{H}_{2} \mathrm{O}$}

1. Set up a reflux condenser with an oil bath or heating mantle and a thermometer.

2. Dissolve $5.34 \mathrm{~g}$ hexamminecobalt(III) chloride in 140 to $150 \mathrm{~mL}$ distilled water in a 500-mL round-bottom flask.

3. Deoxygenate the solution by bubbling with inert gas (nitrogen or argon) for 15 to 30 $\min$.

4. Add $12.12 \mathrm{~g}$ L-cysteine and $16.84 \mathrm{~g}$ potassium hydroxide and heat in the oil bath or heating mantle to $70^{\circ} \mathrm{C}$. Monitor the presence of ammonia by holding moistened $\mathrm{pH}$ paper over the outlet of the reflux condenser, and maintain the temperature until no further evolution of gaseous ammonia can be detected.

The total reaction time is typically $24 \mathrm{hr}$.

5. Add 140 to $150 \mathrm{~mL}$ of $95 \%$ ethanol to precipitate the green potassium (+)-tris(L-cysteinato-SN)cobaltate(III).

6. Cool the mixture in an ice bath, vacuum filter through a $60-\mathrm{mL}$ coarse-frit funnel using a 500-mL filter flask, and wash the resulting solid with $95 \%$ ethanol.

7. Add $100 \mathrm{~mL}$ of $30 \%$ hydrogen peroxide to another $500-\mathrm{mL}$ round-bottom flask, and slowly add the collected precipitate while rigorously maintaining the solution's temperature below $10^{\circ} \mathrm{C}$ in an ice bath.

The material reacts rapidly, producing a bright yellow solution.

8. Precipitate the potassium (+)-tris(lcysu)cobaltate(III) $6 \mathrm{H}_{2} \mathrm{O}$ product by adding 200 $\mathrm{mL}$ of $95 \%$ ethanol.

9. Collect the product by vacuum filtration using another $60-\mathrm{mL}$ coarse frit, wash the solid with $95 \%$ ethanol, and dry under vacuum.

The $\mathrm{K}\left[\mathrm{Co}(\text { lcysu })_{3}\right] \cdot 6 \mathrm{H}_{2} \mathrm{O}$ complex is light sensitive and should be stored in the dark for up to 1 to 2 months at $4^{\circ} \mathrm{C}$. In addition, columns run with solutions of the complex should be protected from light by aluminum foil to minimize breakdown of the eluent.

\section{Perform ion exchange}

10. Prepare a $150 \mathrm{mM} \mathrm{K}\left[\mathrm{Co}(\mathrm{lcysu})_{3}\right]^{3-}$ stock solution by dissolving the dry solid at 110.7 $\mathrm{g} / \mathrm{L}$ in deionized water.

The solution should be used as soon as possible. However, if storage is necessary, it can be stored for up to 1 week at $4^{\circ} \mathrm{C}$ in the dark.

11. Dissolve 30 to $50 \mathrm{mg}\left[\mathrm{Rh}(\text { phen })_{2}(\mathrm{phi})\right] \mathrm{Cl}_{3}$ in a small volume of water (e.g., $\sim 10 \mathrm{~mL}$ or more, depending on solubility).

12. Swell 50 to $100 \mathrm{~g}$ Sephadex CM-C25 ion-exchange resin with 400 to $600 \mathrm{~mL}$ of 0.1 $\mathrm{M} \mathrm{KCl}$ solution in a 1000-mL Erlenmeyer flask for $~ 30 \mathrm{~min}$.

13. Pour the resulting loose suspension into a 2- to 4-foot chromatography column and allow to settle. If an insufficient amount of resin has been added for the desired column length ( 2 to 4 feet), add additional resin before the column has packed down. 
For enantiomer separation, a long column is required. If the column has settled completely and additional resin is added, an interface in the resin will be created that will affect band mobility. If the addition of more resin is necessary after complete column packing, add the resin and then mix the entire column by inversion before allowing it to pack again. This provides a more uniform column and better separation.

14. Wash the column thoroughly with several volumes of deionized water to remove any excess $\mathrm{KCl}$ solution. Drain excess water (i.e., to the level of the packed resin).

If the potassium solution is not completely removed from the column, the cobalt eluent will precipitate on the resin.

15. Carefully load the rhodium solution (step 11) onto the top of the column, taking care not to disturb the resin surface.

The colored complex should stick to the first 0.25 to $0.5 \mathrm{~cm}$ of column packing. If desired, an additional amount of swelled resin can be carefully layered over the product band with a long pipet to serve as a protective layer between the material and added solvent.

16. Run the column using a recirculating pump that circulates a small volume of cobalt eluent through the column at a flow rate of $\sim 1 \mathrm{~mL} / \mathrm{min}$. Begin eluting with a three-fold dilution of the $150 \mathrm{mM}\left[\mathrm{Co}(\mathrm{lcysu})_{3}\right]^{3-}$ stock solution (i.e., $50 \mathrm{mM}$ ), taking care not to disturb the resin bed.

If a recirculating pump is unavailable, it is equally effective to prepare a larger volume of cobalt solution and recirculate it manually over time from a collection vessel at the base of the column to a reservoir above.

17. When the dilute cobalt solution begins to elute through the base of the column, increase the concentration of the eluent to $100 \mathrm{mM}$ for an additional column volume, and then to $150 \mathrm{mM}$ for an additional column volume.

The stepwise equilibration of the column is necessary because the column resin will not contract uniformly if the ionic strength is increased too rapidly. Such nonuniform shrinkage will adversely affect the separation of the metal complex enantiomers.

18. Continue elution until two distinct, separated enantiomer bands are visible (usually a period of several days to two weeks, depending on the elution rate).

Although the yellow color of the cobalt eluent makes it difficult to monitor the progress of the separation, the distinctively darker rhodium bands can usually be discerned.

19. When sufficient separation is obtained, stop elution and rinse the column thoroughly with several column volumes of distilled water to remove as much of the cobalt as possible.

Once the excess eluent is washed out, the orange product bands should be easily located.

\section{Isolate enantiomers}

20. Allow the column to run dry and then expel the resin with air pressure onto a clean, flat surface.

The column should come out as an intact cylinder with the product separation intact. If necessary, compressed air can be forced through the top of the column to remove all excess solvent before expelling the resin. In addition, it is often useful to mark the positions of the column bands on the outside of the column barrel before expelling the resin. The bands are often more difficult to locate in the dry resin, and comparison to the marked column can be very useful. 
21. Excise the bands of the separated enantiomers from the column with a laboratory spatula and place them into two 0.5 - to 1 -foot chromatography columns.

With $\left[\mathrm{Co}(\text { lcysu })_{3}\right]^{3-}$ as the eluent, the delta enantiomer of the rhodium complex elutes faster.

22. Wash with $0.1 \mathrm{M} \mathrm{MgCl}_{2}$ to remove any residual cobalt complex and ensure that the rhodium will have chloride counter ions when eluted from the resin.

23. Elute the separated enantiomers with $1 \mathrm{M} \mathrm{MgCl}_{2}$ and collect in $250-\mathrm{mL}$ Erlenmeyer flasks.

24. Concentrate and desalt the products on Waters Sep-Pak C18 cartridges as described above (see Support Protocol 1, steps 22 to 26).

25. Characterize the product by CD spectroscopy to ensure the success of the enantiomeric separation.

In addition, showing that the CD spectra of the two enantiomers are exact mirror images of one another demonstrates that no contaminating cobalt eluent is present. Spectroscopic data are included below (see Compound Characterization).

\section{SYNTHESIS OF TRIS(PHENANTHROLINE) COMPLEXES OF RUTHENIUM(II)}

In this protocol, modified from Lin et al. (1976), two tris(phenanthroline) complexes, $\left[\mathrm{Ru}(\mathrm{TMP})_{3}\right]^{2+}$ and $\left[\mathrm{Ru}(\mathrm{phen})_{3}\right]^{2+}$, are synthesized by analogous methods in a single step. The ruthenium trichloride starting material is combined with the appropriate phenanthroline ligands and refluxed to allow formation of complexes. The resulting materials are isolated by precipitation, purified by ion-exchange chromatography, and desalted on C18 reversed-phase cartridges.

\section{Additional Materials (also see Support Protocol 1)}

Ruthenium trichloride hydrate

$6 \mathrm{M} \mathrm{HCl}$ solution (see Table A.2A.1)

3,4,7,8-Tetramethyl-1,10-phenanthroline (TMP) or 1,10-phenanthroline (phen)

$30 \%(\mathrm{w} / \mathrm{v})$ hypophosphorus acid solution

$2 \mathrm{M} \mathrm{NaOH}$ solution

30-mL medium-frit glass funnels

\section{Prepare ruthenium complex}

1. Set up a reflux condenser with a temperature-controlled magnetic stir plate, an oil bath or heating mantle, and a 100- to $200-\mathrm{mL}$ round-bottom flask. Heat 60 to $75 \mathrm{~mL}$ distilled water in the flask to $90^{\circ} \mathrm{C}$ with stirring.

2. Add the following:

$0.71 \mathrm{~g}$ ruthenium trichloride hydrate

2 drops $6 \mathrm{M} \mathrm{HCl}$ solution

$2.1 \mathrm{~g}$ TMP or $1.7 \mathrm{~g}$ phen.

NOTE: Stainless steel spatulas should not be used during the synthesis of this material as the phenanthroline ligands will complex with any dissolved iron impurities.

3. Continue heating for 10 to $20 \mathrm{~min}$.

During this time, the dark black solution will change to a dark green color.
SUPPORT PROTOCOL 3

Chemical and Enzymatic Probes for Nucleic Acid Structure 
4. Neutralize $1.7 \mathrm{~mL}$ hypophosphorus acid solution to $\mathrm{pH} 7$ with $\sim 5 \mathrm{~mL}$ of $2 \mathrm{M} \mathrm{NaOH}$ solution and add to the reaction mixture. Continue to reflux for an additional $60 \mathrm{~min}$.

The color will change to orange-red.

5. Remove from heat and filter hot through a 30-mL medium-frit funnel. Discard the precipitate.

6. While stirring, slowly add $20 \mathrm{~mL}$ of $6 \mathrm{M} \mathrm{HCl}$ solution to the filtrate. Collect the orange precipitate that forms by suction filtration.

7. Dissolve the isolated precipitate in a small volume of water and acetonitrile.

The exact mixture depends on solubility. A good procedure is to start with $10 \mathrm{~mL}$ water and add acetonitrile until all material is dissolved (typically 15 to $25 \mathrm{~mL}$ total volume).

\section{Purify product}

8. Prepare a cation-exchange column as described (see Support Protocol 1, steps 18 and 19).

For adequate purification, this column should be $\geq 10 \mathrm{~cm}$ high.

9. Load the entire product solution onto the top of the column with a long pipet, taking care not to unduly disturb the resin surface.

The metal complex will adhere to the resin at the very top of the packed column. Unreacted phenanthroline ligands and any uncharged or anionic side products will flow through immediately.

10. Begin to elute with distilled water. After two to three column volumes of water have passed through and most of the yellow ligand has eluted, change to $0.05 \mathrm{M} \mathrm{MgCl}_{2}$. Increase the salt concentration over time to $0.2 \mathrm{M}$.

The product should come off as a single broad orange band.

11. Collect the fraction in a 500-mL Erlenmeyer flask and isolate the product on a Sep-Pak reversed-phase cartridge as described (see Support Protocol 1, steps 22 to 26).

12. Characterize the products by ${ }^{1} \mathrm{H}$ NMR, UV/visible spectrometry, and mass spectrometry.

Spectroscopic data are included below (see Compound Characterization).

BASIC PROTOCOL 2

Probing Nucleic Acid Structure

\section{SHAPE-SELECTIVE CLEAVAGE OF UNUSUAL STRUCTURES IN NUCLEIC ACIDS}

Tris(4,7-diphenyl-1,10-phenanthroline)rhodium(III), $\left[\mathrm{Rh}(\mathrm{DIP})_{3}\right]^{3+}$, is a shape-selective structure probe of nucleic acids. Because of the sterically bulky phenyl substituents on the phenanthroline ligands (Fig. 6.2.3), this complex, like $\left[\mathrm{Ru}(\mathrm{TMP})_{3}\right]^{2+}$, cannot intercalate easily into B-form DNA. Instead, the hydrophobic complex specifically targets unusual, non-B-form structures. Like other rhodium complexes, the complex promotes direct, photo-induced strand cleavage at sites where it is intimately bound. With much lower efficiency, the complex also damages DNA oxidatively, yielding damage at 5'-GG$3^{\prime}$ and $5^{\prime}$-GA-3' sites analogous to that observed by DNA-mediated electron transfer chemistry (Hall et al., 1996). The unusual structures targeted by the complex have been shown to include cruciforms, Z DNA, and other tertiary sites whose structures are not yet well characterized (Müller et al., 1987; Kirshenbaum et al., 1988; Lee and Barton, 1993). As a result, cleavage at a particular site by $\left[\mathrm{Rh}(\mathrm{DIP})_{3}\right]^{3+}$ does not establish the presence of a particular DNA structure, but rather that the conformation of the nucleic acid at that 


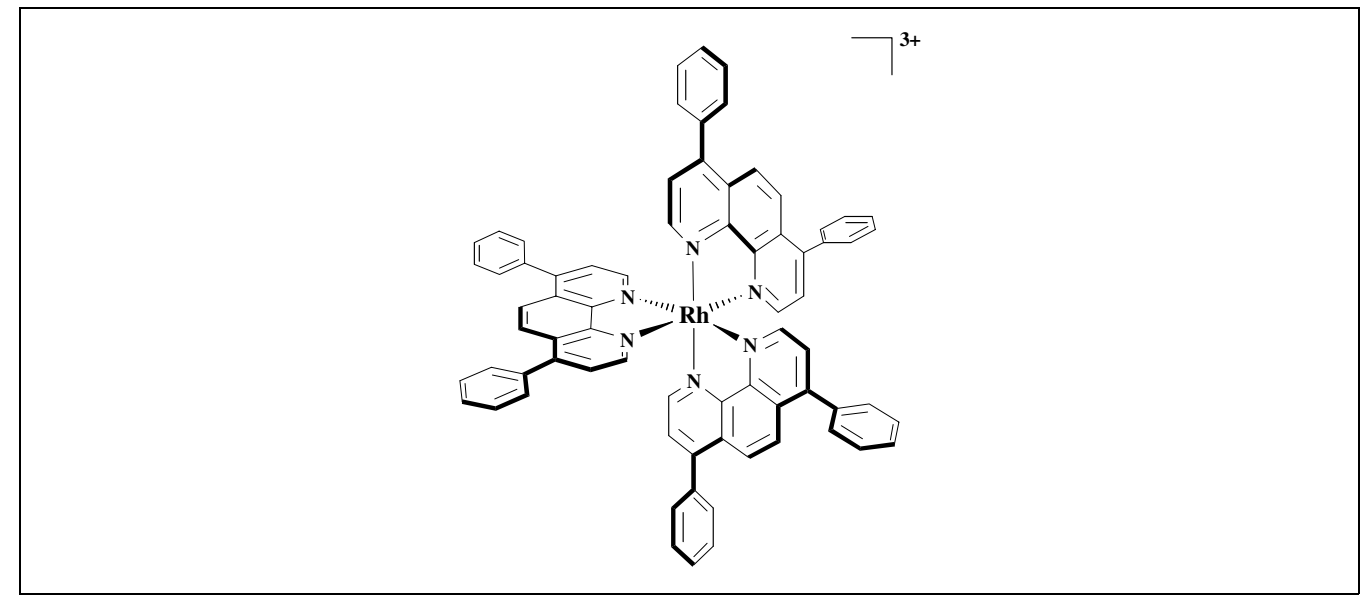

Figure 6.2.3 $\left[\mathrm{Rh}(\mathrm{DIP})_{3}\right]^{3+}$.

site is an unusual one that is neither B nor A form and is not single stranded. For a discussion of nucleic acid structure, see APPENDIX $1 B$.

Because cleavage with $\left[\mathrm{Rh}(\mathrm{DIP})_{3}\right]^{3+}$ is very specific, experiments mapping a large piece of DNA for unusual structural forms are usually performed at low resolution to first identify candidate sites before moving to single-nucleotide resolution. Such experiments can scan an entire plasmid that contains sequences of interest, using agarose gel electrophoresis rather than PAGE to determine whether a $\left[\mathrm{Rh}(\mathrm{DIP})_{3}\right]^{3+}$ cleavage site exists and approximately where it is located. Such low-resolution experiments can be done more quickly than experiments at single-nucleotide resolution, and thus ensure that experimental effort is not dissipated scrupulously screening a piece of DNA with no $\left[\mathrm{Rh}(\mathrm{DIP})_{3}\right]^{3+}$ cleavage sites. Furthermore, this two-stage methodology provides an opportunity to determine whether the rhodium cleavage occurs on both DNA strands or only one and whether it depends on DNA superhelicity. Once sites have been identified at low resolution, restriction fragments of the plasmid or synthetic oligonucleotides containing the identified sites can be photocleaved and assayed by PAGE to determine the individual bases where cleavage takes place.

\section{Materials}

Supercoiled plasmid DNA (either commercial or containing a specific site of interest)

Appropriate restriction enzymes (see steps for details) and buffer systems (according to manufacturer's specifications)

$1 \mu \mathrm{g} / \mathrm{mL}$ ethidium bromide solution (APPENDIX 2A) in water or $1 \times \mathrm{TBE}$ electrophoresis buffer

$7.5 \mathrm{M}$ ammonium acetate solution in deionized water

Absolute ethanol (200 proof, dehydrated)

Dry ice

$10 \times$ Tris/acetate buffer, $\mathrm{pH} 7.0$ (see recipe)

Metal complex solution (see recipe): $20 \mu \mathrm{M} \mathrm{rac}-\left[\mathrm{Rh}(\mathrm{DIP})_{3}\right] \mathrm{Cl}_{3}$ (for synthesis, see Support Protocol 4)

S1 single-strand-specific nuclease and appropriate buffer systems (according to manufacturer's specifications)

$9 \mathrm{mM}$ base pairs of calf thymus DNA solution in deionized water, buffered to $\mathrm{pH} 7$ to 9

DNA molecular weight standards (e.g., commercially available 100-base ladder)

$1 \times$ TBE electrophoresis buffer (APPENDIX 2A)

Loading buffer (e.g., formamide loading buffer or urea loading buffer; see recipes)

Chemical and Enzymatic Probes for Nucleic Acid Structure 
Maxam-Gilbert sequencing reactions on labeled, unirradiated samples of 250- to 500-bp DNA fragment of interest (see Support Protocol 9)

UV transilluminator

Speedvac evaporator (Savant) or lyophilizer

UV/visible spectrometer

$90^{\circ} \mathrm{C}$ heating block

Phosphorimager (optional)

Additional reagents and equipment for restriction digests (e.g., CPMB UNIT 3.1), agarose gel electrophoresis (e.g., CPMB UNIT 2.5), photolysis (see Support Protocol 8), radiolabeling DNA (see Support Protocol 7), nondenaturing PAGE (e.g., CPMB UNIT 2.7A), denaturing PAGE (sequencing gels; APPENDIX 3B), autoradiography (optional; e.g., CPMB APPENDIX $3 A$ ), and mapping cleavage sites (see Support Protocol 9)

NOTE: Because of the low solubility of rac-[Rh(DIP $\left.)_{3}\right] \mathrm{Cl}_{3}$ in water, a more concentrated solution of the material may need to be made in ethanol (or an ethanol/water mixture) and diluted to the desired stock concentration $(20 \mu \mathrm{M})$ with water.

\section{Low-resolution cleavage}

\section{Linearize plasmid DNA}

1. Linearize 20 to $30 \mu \mathrm{g}$ supercoiled plasmid DNA with the appropriate single-cutting restriction enzyme according to manufacturer's instructions (e.g., see CPMB UNIT 3.1).

This amount of DNA should be sufficient for one analysis (e.g., eight sample and control tubes, as described in step 7 below).

The enzyme chosen must have only a single cut site on the plasmid DNA of interest.

2. Verify that the plasmid sample is completely linearized by analyzing $\sim 1 \mu \mathrm{g}$ on a $1 \%$ (w/v) agarose gel. Stain the gel in $1 \mu \mathrm{g} / \mathrm{mL}$ ethidium bromide solution and visualize the stained DNA with a UV transilluminator.

If the sample is not completely digested, retreat with enzyme until it is linearized.

3. Precipitate the remaining DNA by adding $1 / 5$ th to $1 / 4$ th vol of $7.5 \mathrm{M}$ ammonium acetate solution and 4 to $5 \mathrm{vol}$ absolute ethanol, mixing well, and chilling $1 \mathrm{hr}$ on dry ice.

4. Microcentrifuge $12 \mathrm{~min}$ at maximum speed $(14,000 \mathrm{rpm})$, at either room temperature or $4^{\circ} \mathrm{C}$.

5. Decant the supernatant carefully and dry the pellet 15 to 20 min in a Speedvac evaporator or a lyophilizer to remove residual ethanol. Avoid overdrying the pellet or it may adhere to the walls of the microcentrifuge tube.

6. Resuspend DNA in deionized water, determine its concentration (and the concentration of the supercoiled plasmid stock) by UV/visible spectrometry $\left(\varepsilon_{260}=6600 \mathrm{M}^{-1}\right.$ $\mathrm{cm}^{-1}$ per nucleotide), and dilute both to $400 \mu \mathrm{M}$ nucleotides in $2 \times$ Tris/acetate buffer.

Irradiation experiments with both the supercoiled and liner plasmid samples will immediately assess any supercoiling dependence of a structure recognized by $\left[R h(D I P)_{3}\right] C l_{3}$. This is particularly relevant in the case of some cruciform structures that are only extruded from the double-stranded form in the presence of supercoiling strain. 


\section{Cleave DNA}

7. Combine equal volumes of $20 \mu \mathrm{M}$ rac-[Rh(DIP $\left.)_{3}\right] \mathrm{Cl}_{3}$ and $400 \mu \mathrm{M}$ DNA stock solutions as described (see Support Protocol 8, steps 1 to 3), but mix samples only by gentle tapping of the tube. For each plasmid of interest, prepare a light and a dark control and two experimental samples for both the linear and supercoiled forms (total eight tubes).

One half of the experimental samples will be treated with S1 nuclease (see step 11 below). If desired, the dark control can be performed with either linear or supercoiled DNA; both are not required, as they assess contaminants in the metal solution.

Centrifugation of irradiation samples should be avoided because it may result in metal complex precipitation.

8. Irradiate 20 to $60 \mathrm{sec}$ at $330 \mathrm{~nm}$ with a $\mathrm{Hg}$-Xe arc lamp or $10 \mathrm{~min}$ with a transilluminator (see Support Protocol 8, step 4) and precipitate DNA (steps 3 to 5 above).

Under these conditions, photolysis leads to partial or complete conversion of supercoiled samples to nicked or linear plasmid DNA.

9. Resuspend the supercoiled irradiation samples in the buffer appropriate for the enzyme used above and treat with the same restriction enzyme for the same total incubation time as used in step 1.

10. Precipitate samples as in steps 3 to 5 .

11. Treat half of the experimental samples (including both supercoiled and linearized plasmid irradiations) with S1 nuclease according to manufacturer's instructions.

In the authors' experiments this involves buffering DNA solutions to pH 6, adding ?? zinc sulfate, and treating with 10 to 20 units of nuclease for 20 min at $37^{\circ} \mathrm{C}$.

This enzymatic treatment converts any single-strand breaks caused by the complex into double-strand breaks that can be observed in a low-resolution agarose gel experiment. It also provides the opportunity to assess whether there is a supercoiling dependence to the type of strand break induced by the complex.

12. Precipitate samples as in steps 3 to 5.

\section{Analyze samples}

13. Electrophorese $1 \mu \mathrm{g}$ DNA/lane on a $1 \%(\mathrm{w} / \mathrm{v})$ agarose gel. Run DNA molecular weight standards alongside the experimental samples to better assess the approximate position of any breaks vis-a-vis the restriction enzyme site used to linearize the plasmid.

14. Stain the gel in $1 \mu \mathrm{g} / \mathrm{mL}$ ethidium bromide solution and visualize using a transilluminator.

If desired, record data photographically using a Polaroid camera. Negatives of the photographs can be quantitated using a densitometer to determine the exact amounts of conversion of various forms of the plasmid.

\section{High-resolution cleavage}

\section{Linearize plasmid DNA}

15. Linearize DNA as described above (steps 1 to 6), but use an enzyme that has a single cut site within 100 to 300 bp of any interesting structures revealed in the low-resolution experiment.

This will generate pieces that are short enough for adequate resolution.

Chemical and Enzymatic Probes for Nucleic Acid Structure 


\section{Cleave DNA}

16. Irradiate samples as described in steps 7 and 8 above.

Irradiation times for high-resolution experiments must be optimized for a particular system to ensure that the amount of photocleavage is sufficient for PAGE analysis, but that the end-labeled DNA is not overcleaved. To determine an acceptable irradiation time, prepare a set of identical samples and irradiate each for steadily increasing times. A good starting point is $\sim 5$ min at $330 \mathrm{~nm}$. Select an irradiation time where the cleavage bands are easily observable on the gel but where most of the full-length DNA band ( $\geq 90 \%)$ remains uncleaved.

At long irradiation times, in the absence of strong binding sites for the complex, non-structure-specific damage is observed at $5^{\prime}-G G-3^{\prime}$ and $5^{\prime}-G A-3^{\prime}$ sites. This should not be confused with structure-specific cleavage.

17. Precipitate all samples by adding 1 to $5 \mu \mathrm{L}$ of $9 \mathrm{mM}$ calf thymus DNA, $1 / 6$ th to $1 / 4$ th vol of $7.5 \mathrm{M}$ ammonium acetate, and $5 \mathrm{vol}$ absolute ethanol. Mix well and heat to $90^{\circ} \mathrm{C}$ for $5 \mathrm{~min}$. Mix again and incubate on dry ice for $30 \mathrm{~min}$.

Heating ensures complete dissociation of the metal-DNA complex prior to precipitation. It is important to remove the metal complex as it can affect the electrophoretic mobility of the DNA products.

18. Microcentrifuge $12 \mathrm{~min}$ at maximum speed (14,000 rpm).

19. Carefully remove the supernatants, resuspend each pellet in 50 to $100 \mu \mathrm{L}$ water, and repeat steps 17 and 18, but without heating.

20. Remove the supernatants, rinse the resulting pellets twice with cold $80 \%(\mathrm{v} / \mathrm{v})$ ethanol, and dry under vacuum.

21. Treat supercoiled samples with restriction enzyme (as in step 15) and precipitate as described in steps 17,18 and 20, but without heating.

\section{Analyze samples}

22. Resuspend all samples in deionized water and label them with $\left[{ }^{32} \mathrm{P}\right]$ phosphate or $\left[{ }^{32} \mathrm{P}\right]$ nucleotides (see Support Protocol 7).

Labeling of the $5^{\prime}$ end of the plasmid will require dephosphorylation with a phosphatase and then rephosphorylation with $\left[\gamma_{-}{ }^{32} P\right] A T P$. Labeling at the $3^{\prime}$ end is routinely done by filling in the overhang left by the restriction enzyme with an appropriate polymerase and radiolabeled nucleoside triphosphates.

23. Cut DNA with an additional restriction enzyme selected to excise the region of interest in a segment that is 250 to 500 bp long.

24. Isolate the desired fragment on a 5\% to $10 \%$ nondenaturing polyacrylamide gel.

25. Identify the position of the band of interest by autoradiography, excise the gel band, and isolate the labeled DNA by soaking the gel slice 2 to $4 \mathrm{hr}$ in $1 \times$ TBE electrophoresis buffer.

The progress of elution can be monitored by comparing the amount of radiation in the supernatant to that remaining in the gel.

26. Precipitate the isolated DNA (steps 17 to 20).

27. Resuspend in denaturing loading buffer, heat 2.5 to $5 \mathrm{~min}$ at $90^{\circ} \mathrm{C}$, and resolve on a $6 \%$ to $8 \%$ denaturing polyacrylamide sequencing gel. Run with Maxam-Gilbert sequencing reactions on labeled, unirradiated samples of the same DNA fragment (see Support Protocol 9). Visualize results by autoradiography or by phosphorimagery. 


\section{SYNTHESIS OF TRIS(4,7-DIPHENYL-1,10-PHENANTHROLINE) RHODIUM(III) TRICHLORIDE}

In this protocol, which is modified from Gidney et al. (1972), $\left[\mathrm{Rh}(\mathrm{DIP})_{3}\right]^{3+}$ is synthesized in a single step from rhodium trichloride and 4,7-diphenyl-1,10-phenathroline (DIP). The product is isolated by precipitation. Because of the low solubility of the complex in all solvents applicable for ion-exchange chromatography, the product is purified by recrystallization.

\section{Additional Materials (also see Support Protocol 1)}

4,7-Diphenyl-1,10-phenanthroline (DIP)

$2.5 \mathrm{mg} / \mathrm{mL}$ hydrazine monohydrochloride in water

Saturated $\mathrm{NaCl}$ solution

Acetone

100-mL Erlenmeyer flask

30-mL medium-frit glass funnel

100-mL filter flask

1. Set up a reflux condenser with a temperature-controlled magnetic stir plate and an oil bath or heating mantle.

2. Dissolve $50 \mathrm{mg}$ rhodium trichloride monohydrate in $10 \mathrm{~mL}$ deionized water in a 50 -mL round-bottom flask.

3. Dissolve $200 \mathrm{mg}$ of 4,7-diphenyl-1,10-phenanthroline in $10 \mathrm{~mL}$ of hot $\left(80^{\circ} \mathrm{C}\right) 95 \%$ ethanol in another 50-mL round-bottom flask. While stirring, add the ligand solution to the rhodium solution.

Some precipitation may occur.

NOTE: No stainless steel spatulas should be used during the synthesis of this material as the phenanthroline ligands will complex with any dissolved iron impurities.

4. Add $1 \mathrm{~mL}$ of $2.5 \mathrm{mg} / \mathrm{mL}$ hydrazine monohydrochloride to the reaction mixture.

5. Connect the reaction flask to the condenser and bring to reflux. Continue to reflux the mixture for $72 \mathrm{hr}$.

After 30 min the solution should be clear yellow. Over the 72-hr period, it should become bright orange.

6. Allow the reaction to cool and remove the solvent using a rotary evaporator with a vacuum pump.

This should yield a yellow-orange solid.

A yellow side product of the reaction is often produced along with the desired complex. It has been assigned, by NMR and mass spectrometry, as [Rh(DIP $\left.)_{2} \mathrm{Cl}_{2}\right] \mathrm{Cl}$. It is much less soluble in ethanol than the desired trischelate complex and can be separated on that basis in the following recrystallization step. Presence of red or pink coloration indicates contamination by iron complexes.

7. Transfer the solid to a $100-\mathrm{mL}$ Erlenmeyer flask and recrystallize from $50 \mathrm{~mL}$ of hot $1: 1(\mathrm{v} / \mathrm{v})$ ethanol/water containing $1 \mathrm{~mL}$ saturated $\mathrm{NaCl}$ solution.

8. Quickly decant the complex solution from any residual solid and allow to cool to room temperature. Chill at $4^{\circ} \mathrm{C}$ for several hours to ensure that crystallization is as complete as possible.
Chemical and Enzymatic Probes for Nucleic Acid Structure 
Because of the low solubility of the material, the crystals will come out very quickly once the solution begins to cool.

9. Collect the product by vacuum filtration using a $30-\mathrm{mL}$ medium-frit glass funnel.

This should yield peach-colored crystals. Impurities (e.g., red iron complexes) cause significant changes in color. If necessary, the resulting solid can be recrystallized by dissolving in a minimum volume of ethanol and pouring the resulting solution into a large volume (200 to $250 \mathrm{~mL}$ ) of acetone.

Because of the low solubility of this compound in all solvents applicable for ion-exchange chromatography, purification of the material using that methodology is not practical.

Spectroscopic data are included below (see Compound Characterization).

BASIC PROTOCOL 3
Probing Nucleic Acid Structure

\section{RECOGNITION OF MISMATCHES AND ABASIC SITES IN DNA}

In addition to the use of shape-selective ancillary ligands to probe the characteristics of the grooves or structures of DNA as discussed with $\left[\mathrm{Ru}(\mathrm{TMP})_{3}\right]^{2+}$ and $\left[\mathrm{Rh}(\mathrm{DIP})_{3}\right]^{3+}$, shape-selective intercalating ligands can be used to probe differences in base pairing at the core of the DNA helix. Bis(2,2'-bipyridine)(5,6-chrysenequinone diimine)rho$\operatorname{dium}(\mathrm{III}),\left[\mathrm{Rh}(\mathrm{bpy})_{2} \text { (chrysi) }\right]^{3+}$ (see Fig. 6.2.4), is such a complex that utilizes a broad, four-ring chrysenequinone diimine intercalating ligand. Like $\left[\mathrm{Rh}(\mathrm{DIP})_{3}\right]^{3+}$, where the size of substituents on the ancillary ligands only allows interaction at sites of tertiary structure, the steric bulk of the chrysi ligand prevents it from intercalating into DNA except at sites where disrupted base pairing opens up the structure of the helix. This selectivity has been applied to the recognition of the destabilized helical structures characteristic of both mismatched base pairs in DNA (Jackson and Barton, 1997) and abasic sites (B.A. Jackson and J.K. Barton, unpub. observ.). Although the recognition properties of the two enantiomers of the complex are different, racemic material is sufficient for routine experiments.

Photocleavage experiments with $\left[\mathrm{Rh}(\mathrm{bpy})_{2} \text { (chrysi) }\right]^{3+}$ are performed as described (see Support Protocol 8). Since the structures that are probed with this molecule (i.e., mismatches and abasic sites) are not generally found at specific sites of plasmid restriction fragments, experiments are routinely done on synthetic oligonucleotides. As a result, DNA concentrations are expressed in terms of polymers rather than concentration of base pairs or nucleotides.

\section{Materials}

Metal complex solution (see recipe): $\operatorname{rac}-\left[\mathrm{Rh}(\mathrm{bpy})_{2}(\mathrm{chrysi}) \mathrm{Cl}_{3}\right.$ solution (typically $2 \mu \mathrm{M}$; for synthesis, see Support Protocol 5)

Labeled DNA solution (see Support Protocol 7): typically $20 \mu \mathrm{M}$ polymers in $2 \times$ buffer

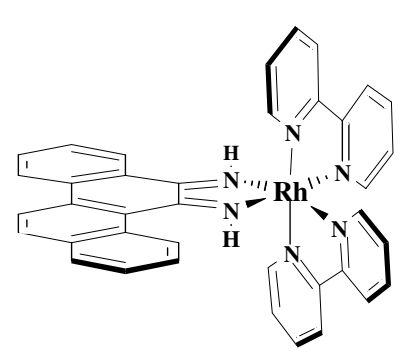

Figure 6.2.4 $\left[\mathrm{Rh}(\mathrm{bpy})_{2}(\text { chrysi })\right]^{3+}$. 
Additional reagents and equipment for photolysis (see Support Protocol 8) and for mapping cleavage sites (see Support Protocol 9)

1. Mix equal volumes of rac-[Rh(bpy $)_{2}($ chrysi) $] \mathrm{Cl}_{3}$ solution and labeled DNA solution for a total volume of 10 to $50 \mu \mathrm{L}$ as described (see Support Protocol 8, steps 1 to 3). Set up dark and light controls for each DNA of interest.

2. Irradiate $5 \mathrm{~min}$ at $313 \mathrm{~nm}$ or 15 to $30 \mathrm{~min}$ at $365 \mathrm{~nm}$ and treat as described (see Support Protocol 8, steps 4 to 8 ).

3. Perform electrophoresis and autoradiography as described (see Support Protocol 9).

Sites of $\left[R h(\text { bpy })_{2}(\text { chrysi })\right]^{3+}$ binding are indicated by cleavage bands in the experimental lanes.

4. Identify specific sites of cleavage by comparing to Maxam-Gilbert sequencing reactions as described in Support Protocol 9.

Although cleavage band intensity is related to the affinity of the complex for individual DNA sites, differences in photocleavage efficiency from site to site make direct comparisons difficult.

\section{SYNTHESIS OF BIS(2,2'-BIPYRIDINE)(5,6-CHRYSENEQUINONE DIIMINE)RHODIUM(III) TRICHLORIDE}

$\left[\mathrm{Rh}(\mathrm{bpy})_{2}(\text { chrysi) }]^{3+}\right.$ is synthesized using the same condensation chemistry described for the synthesis of $[\mathrm{Rh} \text { (phen) })_{2}$ (phi) $]^{3+}$ (see Support Protocol 1) and is modified from Mürner et al. (1998). The $\left[\mathrm{Rh}(\mathrm{bpy})_{2} \mathrm{Cl}_{2}\right] \mathrm{Cl}$ intermediate is made using the same protocol, except that bipyridine is substituted for the phenanthroline ancillary ligands. It is then converted to the diammine complex and condensed with chrysenequinone. Because chrysenequinone is not commercially available, its one-step synthesis from the parent aromatic hydrocarbon is also described (Mürner et al., 1998; originally from Greabe and Hönigsberger, 1900).

\section{Additional Materials (also see Support Protocol 1)}

Chrysene

Sodium dichromate

Glacial acetic acid

$2,2^{\prime}$-Bipyridine

Mortar and pestle

250- and 1000- to 2000-mL round-bottom flasks

250-mL beaker

60-mL coarse-frit glass funnels

250- and 1000-mL filter flasks

2000-mL Erlenmeyer flask

\section{Synthesize 5,6-chrysenequinone}

1. Set up a reflux condenser with a temperature-controlled magnetic stir plate and an oil bath or heating mantle.

2. Grind $5 \mathrm{~g}$ chrysene into a fine powder with a mortar and pestle.

This procedure ensures that the material will be oxidized efficiently, and is necessary when the chrysene is in the form of crystalline "chunks." If it can be obtained as a fine powder, further grinding is not required.

SUPPORT PROTOCOL 5

Chemical and Enzymatic Probes for Nucleic Acid Structure 
CAUTION: To prevent exposure to the fine dust produced in this procedure, the grinding should be performed in a fume hood. In addition, appropriate personal safety devices should be used, including gloves, a laboratory coat, and a face mask.

3. Add the $5 \mathrm{~g}$ chrysene and $20 \mathrm{~g}$ sodium dichromate to a 250 -mL round-bottom flask.

4. Add $50 \mathrm{~g}$ glacial acetic acid, connect the flask to a condenser, and bring the mixture to reflux with stirring. Continue refluxing for a total of $9 \mathrm{hr}$.

As heating continues, the solution will change from the orange-yellow of the dichromate/chrysene to a deep green with visible orange-red crystals of the chrysenequinone product.

5. Remove the reaction mixture from heat and immediately add to a $250-\mathrm{mL}$ beaker containing 75 to $100 \mathrm{~mL}$ boiling distilled water.

The product will crash out of solution while the green chromium by-products remain soluble.

6. Collect the product by filtering the solution through a $60-\mathrm{mL}$ coarse-frit glass funnel using a $250-\mathrm{mL}$ filter flask and a water aspirator or vacuum pump.

7. Wash crystals thoroughly with 250 to $500 \mathrm{~mL}$ water.

Recoveries at this step are typically $80 \%$ to $90 \%$.

\section{Recrystallize 5,6-chrysenequinone}

8. Place $\sim 0.8$ to $0.9 \mathrm{~g}$ product into a $1000-\mathrm{mL}$ round-bottom flask and add $\sim 800$ to 900 $\mathrm{mL}$ of $95 \%$ ethanol ( $\sim 1$ liter per gram of solid).

9. Connect to the reflux condenser and bring to a boil with stirring.

The solution should become a clear orange-red color. If there are still orange crystals that remain undissolved, more ethanol should be added. However, any yellow chrysene starting material should not dissolve.

10. Decant the hot solution away from any undissolved material into a $2000-\mathrm{mL}$ Erlenmeyer flask. Allow the solution to cool to room temperature, then chill to $4^{\circ} \mathrm{C}$ for several hours to promote further crystallization.

11. Collect the product by filtration with a $60-\mathrm{mL}$ coarse-frit glass funnel and a $1000-\mathrm{mL}$ filter flask.

12. Rinse with a small volume of ethanol (e.g., 50 to $100 \mathrm{~mL}$ ) and dry the isolated product under vacuum.

13. Characterize the product by ${ }^{1} \mathrm{H}$ NMR and mass spectrometry.

Spectroscopic data are included below (see Compound Characterization).

\section{Synthesize [Rh(bpy) $)_{2}$ (chrysi) $]^{3+}$}

14. Prepare $\left[\mathrm{Rh}(\mathrm{bpy})_{2}\left(\mathrm{NH}_{3}\right)_{2}\right] \mathrm{Cl}_{3}$ intermediate as described for $\left[\mathrm{Rh}(\mathrm{phen})_{2}\left(\mathrm{NH}_{3}\right)_{2}\right] \mathrm{Cl}_{3}$ (see Support Protocol 1, steps 1 to 13), but substitute 2,2'-bipyridine for the phenanthroline ancillary ligands.

Spectroscopic data are included below (see Compound Characterization).

15. Prepare $\left[\mathrm{Rh}(\mathrm{bpy})_{2} \text { (chrysi) }\right]^{3+}$ by condensation of $\left[\mathrm{Rh}(\mathrm{bpy})_{2}\left(\mathrm{NH}_{3}\right)_{2}\right] \mathrm{Cl}_{3}$ with purified 5,6-chrysenequinone as described for the synthesis of $\left[\mathrm{Rh}(\mathrm{phen})_{2}(\mathrm{phi})\right] \mathrm{Cl}_{3}$ (see Support Protocol 1, steps 14 to 29), adjusting the amounts of materials commensurate with their different molecular weights. 
5,6-Chrysenequinone is less soluble in the acetonitrile/water solvent system but, as the reaction progresses, undissolved starting material goes into solution as the dissolved quinone is consumed. Unlike the previous synthesis, which went from yellow to orange, the color change here is more subtle. The formation of the diimine product gradually changes the red-orange of the quinone solution to a dark brown. After the reaction is completed, ion-exchange purification is done identically as described above. The products should be characterized by ${ }^{l} H$ NMR, UV/visible spectrometry, and mass spectrometry. Spectroscopic data are included below (see Compound Characterization).

\section{PHOTOFOOTPRINTING OF DNA-BINDING MOLECULES}

The complex bis(9,10-phenanthrenequinone diimine)(2,2'-bipyridyl)rhodium(III), $\left[\mathrm{Rh}(\mathrm{phi})_{2}(\mathrm{bpy})\right]^{3+}$, is a strong, sequence-neutral DNA-binding molecule. As with the complexes discussed above, it also cleaves DNA upon photoactivation. This neutral binding behavior and photocleavage can be applied to the footprinting of both DNA-binding proteins and small DNA-binding molecules. Because the cleavage chemistry involves direct reaction rather than a diffusible species, high-resolution footprints are obtained. Since the intercalative interaction of the molecule "senses" both grooves of the DNA helix, these molecules can be used to footprint molecules that bind in either the major or the minor groove (Uchida et al., 1989).

\section{Materials}

Metal complex solution (see recipe): $\left[\mathrm{Rh}(\mathrm{phi})_{2}(\mathrm{bpy})\right] \mathrm{Cl}_{3}$ solution (typically 10 $\mu \mathrm{M}$; for synthesis, see Support Protocol 6)

Labeled DNA solution (see Support Protocol 7): typically $10 \mu \mathrm{M}$ base pairs in a $2 \times$ buffer appropriate to the DNA binding molecule of interest

Labeled DNA/binding molecule solution: labeled DNA solution containing DNA-binding molecule at twice the concentration desired in the photofootprinting experiment

Additional reagents and equipment for photolysis (see Support Protocol 8) and mapping cleavage sites (see Support Protocol 9)

1. Mix equal volumes of $\left[\mathrm{Rh}(\mathrm{phi})_{2}(\mathrm{bpy})\right] \mathrm{Cl}_{3}$ and labeled DNA solutions for a total volume of 10 to $50 \mu \mathrm{L}$ as described (see Support Protocol 8, steps 1 to 3). Set up dark and light controls of each DNA of interest.

It is important to keep a 1:1 ratio between the rhodium complex and the DNA base pairs in the experiment to preserve the sequence neutrality of the cleavage reagent. Some selectivity is observed at low Rh/DNA ratios.

2. Set up separate reactions and controls using the labeled DNA/binding molecule solution.

3. Irradiate 5 to $10 \mathrm{~min}$ at $313 \mathrm{~nm}$ and treat as described (see Support Protocol 8, steps 4 to 8$)$.

4. Perform electrophoresis and autoradiography as described (see Support Protocol 9).

Sites of DNA binding by the molecule of interest will be obvious from the attenuation of rhodium complex cleavage.

5. Identify specific bases of protection by comparison with Maxam-Gilbert sequencing reactions as described in Support Protocol 9.

For more complete characterization of a DNA-binding interaction, multiple footprinting reactions (with a set amount of DNA and rhodium complex) can be performed at different
BASIC

PROTOCOL 4

Chemical and Enzymatic Probes for Nucleic Acid Structure 
SUPPORT PROTOCOL 6
Probing Nucleic Acid Structure concentrations of DNA-binding molecule to titrate in the cleavage footprint. Weaker protection is observed at lower concentrations.

\section{SYNTHESIS OF BIS(9,10-PHENANTHRENEQUINONE DIIMINE)(2,2'-BIPYRIDYL)RHODIUM(III) TRICHLORIDE}

$\left[\mathrm{Rh}(\mathrm{phi})_{2}(\mathrm{bpy})\right]^{3+}$ is synthesized in the two-step process shown in Figure 6.2.5. In this methodology, 9,10-diaminophenanthrene (phi) is used to generate a $\left[\mathrm{Rh}(\mathrm{phi})_{2} \mathrm{Cl}_{2}\right] \mathrm{Cl}$ complex (from Pyle et al., 1990). Before introduction of the third chelating ligand, the chloride ligands are removed with silver triflate. Preparation of $\left[\mathrm{Rh}(\mathrm{phi})_{2}(\mathrm{bpy})\right]^{3+}$ is from Howells and McCown (1977) and Pyle et al. (1990). Although this reaction is described on a relatively large scale, it can be scaled down without difficulty.

In addition to the procedure described here for the synthesis of $\left[\mathrm{Rh}(\mathrm{phi})_{2}(\mathrm{bpy})\right]^{3+}$, a synthesis based on the condensation methodology described above for $\left[\mathrm{Rh}(\mathrm{phen})_{2}(\mathrm{phi})\right]^{3+}$ (see Support Protocol 2) would also be an effective method to make this molecule. Although specific reaction conditions have not been determined to produce the bipyridyl complex, methods have been developed to make the very similar $\left[\mathrm{Rh}(\mathrm{phi})_{2}(\mathrm{phen})\right]^{3+}$. The conditions required to make this molecule are likely to be almost identical (Mürner et al., 1998).

\section{Additional Materials (also see Support Protocol 1)}

9,10-Diaminophenanthrene

Dimethylformamide

Argon gas

Absolute ethanol (anhydrous)

Chloroform

Silver trifluoromethanesulfonate (silver triflate)

$2,2^{\prime}$-Bipyridine

$50 \%(\mathrm{v} / \mathrm{v})$ acetonitrile (reagent grade or better) in distilled water
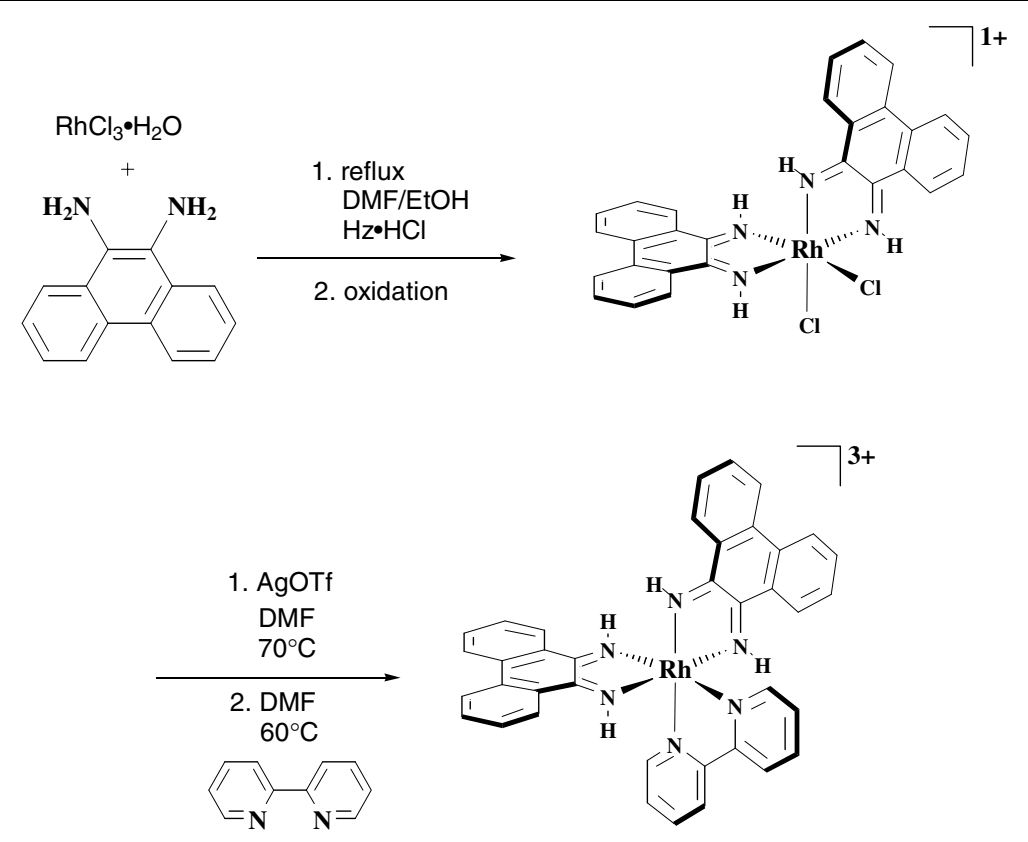

Figure 6.2.5 Synthesis of $\left[\mathrm{Rh}(\mathrm{phi})_{2}(\mathrm{bpy})\right]^{3+}$. AgOTf, silver triflate; DMF, dimethylformamide; $\mathrm{Hz} \cdot \mathrm{HCl}$, hydrazine monohydrochloride. 
Sephadex QAE-25 anion-exchange resin

$1 \mathrm{M} \mathrm{HCl}$ (APPENDIX 2A)

Sephadex CM-C25 cation-exchange resin

1000-mL three-necked, round-bottom flasks

Vacuum line with argon flush

100-, 250-,and 500-mL round-bottom flasks

Septa to fit flasks

Heat gun

60-mL gas-tight syringe with long needle

25-, 500-, and 1000-mL Erlenmeyer flasks

$60-\mathrm{mL}$ coarse- and fine-frit glass funnels

Chromatography columns:

0.5 to 1 feet $(15$ to $30 \mathrm{~cm})$ long, 1 to 1.5 in. $(2.5$ to $3.8 \mathrm{~cm})$ diameter

1 to 2 feet ( 30 to $61 \mathrm{~cm})$ long, 1 to $1.5 \mathrm{in}$. $(2.5$ to $3.8 \mathrm{~cm})$ diameter

\section{Prepare $\left[\mathrm{Rh}(\mathrm{phi})_{2} \mathrm{Cl}_{2}\right] \mathrm{Cl}$}

1. Set up a reflux condenser with a temperature-controlled magnetic stir plate and an oil bath or heating mantle.

2. Combine $3.5 \mathrm{~g}$ of 9,10-diaminophenanthrene and 65 to $75 \mathrm{mg}$ hydrazine monohydrochloride in a $1000-\mathrm{mL}$ three-necked, round-bottom flask.

3. Add $250 \mathrm{~mL}$ dimethylformamide and immediately connect the flask to the reflux condenser, seal it with septa, and begin stirring the mixture to dissolve the reactants.

4. While stirring, deoxygenate the solution by pumping and backfilling with argon gas. Repeat deoxygenation at least three times.

5. In a $250-\mathrm{mL}$ round-bottom flask, add $80 \mathrm{~mL}$ absolute ethanol to $1.6 \mathrm{~g}$ rhodium trichloride monohydrate. Dissolve the rhodium completely by swirling the flask and applying gentle heat with a heat gun.

6. Seal the flask with a septum and deoxygenate as described in step 4 by piercing the septum with a long syringe needle connected to the argon/vacuum line.

7. When both flasks are completely deoxygenated, transfer the rhodium solution to the three-neck reaction flask with a 60 -mL gas-tight syringe.

8. Deoxygenate the reaction mixture again by repeated pumping down and backfilling with argon.

9. Heat the reaction at $80^{\circ} \mathrm{C}$ under argon for 16 to $24 \mathrm{hr}$.

10. Remove from heat and transfer to a $1000-\mathrm{mL}$ Erlenmeyer flask. Open the mixture to air and stir for several days to allow oxidation of the coordinated amines to immine ligands.

11. Collect the product by filtration through a $60-\mathrm{mL}$ coarse-frit glass funnel using a $250-\mathrm{mL}$ filter flask and an aspirator or vacuum pump.

12. Wash with copious amounts ( $100 \mathrm{~mL}$ each) of distilled water, ethanol, and chloroform (in that order).

13. Characterize the product by ${ }^{1} \mathrm{H}$ NMR and mass spectrometry.

Spectroscopic data are included below (see Compound Characterization). Spectroscopy shows that both a trans and a cis product are produced in this reaction. Both isomers, however, can go on to react with an additional chelating ligand to form the desired product.

Chemical and Enzymatic Probes for Nucleic Acid Structure 
Prepare $\left[R h(\text { phi })_{2}(\text { bpy })\right]^{3+}$

14. Dissolve $1 \mathrm{~g}\left[\mathrm{Rh}(\mathrm{phi})_{2} \mathrm{Cl}_{2}\right] \mathrm{Cl}$ in $40 \mathrm{~mL}$ dimethylformamide in a $100-\mathrm{mL}$ round-bottom flask.

15. In a $25-\mathrm{mL}$ Erlenmeyer flask, dissolve $1.25 \mathrm{~g}$ silver triflate in $8 \mathrm{~mL}$ dimethylformamide.

16. Add the silver triflate solution to the rhodium complex, deoxygenate the reaction, and heat to $70^{\circ} \mathrm{C}$. Continue heating for $48 \mathrm{hr}$ under argon.

17. Remove the dark silver chloride precipitate by vacuum filtration, first through a 60 $\mathrm{mL}$ coarse and then through a $60-\mathrm{mL}$ fine frit, using a $250-\mathrm{mL}$ filter flask and an aspirator or vacuum pump.

18. Rinse the precipitate with $50 \mathrm{~mL}$ dimethylformamide to bring the total volume of the filtrate to $\sim 100 \mathrm{~mL}$.

19. Transfer the triflate intermediate solution to a $250-\mathrm{mL}$ round-bottom flask and add $0.5 \mathrm{~g}$ ( 2 eq) of 2,2'-bipyridine chelating ligand.

To ensure as complete a reaction as possible, an excess of ligand should be added.

20. Deoxygenate the reaction mixture several times, then stir at $60^{\circ} \mathrm{C}$ under argon for 24 hr.

21. Remove the solvent using a rotary evaporator with a vacuum pump, and dissolve the product in 10 to $20 \mathrm{~mL}$ of $50 \%$ acetonitrile for chromatography.

The product is now ready for anion-exchange chromatography, which exchanges any of the triflate counter-ions in the reaction for chloride ions. This will improve the solubility of the complex in water and help in the subsequent cation-exchange purification column.

\section{Purify by anion exchange}

22. Swell a small amount (10 to $20 \mathrm{~g}$ ) of Sephadex QAE-25 anion-exchange resin in 50 to $100 \mathrm{~mL}$ of $50 \%$ acetonitrile containing $0.1 \mathrm{M} \mathrm{HCl}$ in a $500-\mathrm{mL}$ Erlenmeyer flask.

23. Pour the slurry into a 0.5 - to 1 -foot column and allow it to pack to a height of 5 to 7 inches $(13$ to $18 \mathrm{~cm})$.

24. Wash the column with one to two column volumes of $50 \%$ acetonitrile. When the level of the solvent approaches the top of the resin, pour the product solution into the column and immediately begin collecting the effluent.

Although it is desirable to keep the packing as undisturbed as possible, it is not necessary to worry too much about agitating the top of the column. It is necessary to begin collecting immediately because the reaction mixture will flow straight through.

25. Collect all the metal complex off the anion-exchange column by washing it with one to two column volumes of $50 \%$ acetonitrile.

26. Transfer the fraction to a 500-mL round-bottom flask and remove the solvent using a rotary evaporator.

\section{Purify by cation exchange}

27. Swell 25 to $50 \mathrm{~g}$ Sephadex CM-C25 cation-exchange resin in 200 to $400 \mathrm{~mL}$ of $50 \%$ acetonitrile containing $0.1 \mathrm{M} \mathrm{HCl}$. Pour a 1- to 2-foot column and allow the resin to settle.

Probing Nucleic Acid Structure

28. Wash the column with one to two column volumes of $50 \%$ acetonitrile. 
The mixture of acetonitrile, water, and Sephadex CM resin is used instead of the SP resin used in previous protocols to prevent the complex from sticking irreversibly to the chromatography column.

29. Dissolve the dried product (step 25) in a minimum volume of $50 \%$ acetonitrile (just enough to dissolve all the solid) and load carefully to the top of the cation-exchange column, taking care not to disturb the resin surface.

All the orange metal complex should adhere to the top $1 / 4$ to $1 / 2$ inch of column packing.

If desired, a small layer of swelled resin may be added over the top of the product band using a long pipet. This protective layer prevents disruption of the product band when solvent is subsequently added.

30. Begin eluting the column with $50 \%$ acetonitrile. Increase the concentration of $\mathrm{HCl}$ first to $0.05 \mathrm{M}$ and then gradually to $0.25 \mathrm{M}$ to elute the charged metal complexes.

Typically 100 to $200 \mathrm{~mL}$ of each molarity are used, but this depends of the results obtained. If not bands move at a given molarity, the entire volume need not be used. If bands move at a reasonable rate, the volume can be increased to 400 to $500 \mathrm{~mL}$ to elute a given product band.

Any ligand or ligand breakdown products that remained in the reaction mixture will come off the column immediately. Any remaining rhodium phi starting materials should elute next. The $\left[R h(p h i)_{2}(\right.$ bpy) $] C l_{3}$ will elute last as an intense orange band.

31. To isolate the product from the appropriate fraction, evaporate the solvent to dryness by rotary evaporation or lyophilization.

Residual hydrochloric acid can be removed by repeatedly dissolving the material in methanol and redrying. If desired, the product can be more completely desalted by dissolving in water and using a Waters Sep-Pak reversed-phase cartridge as described earlier (see Support Protocol 1, steps 22 to 26).

32. Characterize the product by ${ }^{1} \mathrm{H}$ NMR, UV/visible spectrometry, and mass spectrometry.

Spectroscopic data are included below (see Compound Characterization).

\section{SHAPE-SELECTIVE CLEAVAGE OF RNA}

Some of the complexes described above for the shape-selective recognition of DNA can also be applied to the study of RNA structural forms. Their utility as structural probes of RNA is considerable, and the sites targeted tend to be unique for current RNA chemical probes. $\left[\mathrm{Rh}(\mathrm{phen})_{2}(\mathrm{phi})\right]^{3+}$ (see Basic Protocol 1) is particularly valuable as a probe of RNA structure. Because of the preference of RNA duplexes to adopt the A form, recognition by $\left[\mathrm{Rh}(\text { phen })_{2} \text { (phi) }\right]^{3+}$ becomes much more specific on RNA than on B-form DNA. Because of its width and depth, the A-form region is not bound by $\left[\mathrm{Rh}(\mathrm{phen})_{2}(\mathrm{phi})\right]^{3+}$. Hence, on folded RNA, the complex can bind only to areas of tertiary interaction or to sites where the major groove has become substantially opened and accessible to intercalation. At such points (e.g., the D-T loop on tRNA ${ }^{\text {Phe }}$, triply bonded sites, and helix-loop junctions), the major groove of the nucleic acid is accessible. This selective identification of sites of tertiary interactions is a very useful tool in exploring the three-dimensional structure of an unknown segment of RNA. It is noteworthy that sites that are opened in the major groove are often specific targets for RNA-binding proteins. As a result, such structural information could find application not only in the study of the nucleic acids themselves but in the rapidly expanding study of RNA-protein interactions.

BASIC PROTOCOL 5

Chemical and Enzymatic Probes for Nucleic Acid Structure 
$\left[\mathrm{Rh}(\mathrm{DIP})_{3}\right]^{3+}$ (see Basic Protocol 2) recognizes and cuts RNA in areas of folded loops. This recognition is similar to the recognition of DNA cruciforms, which is assumed to be a mostly hydrophobic interaction with areas of the molecule that are not purely double or single stranded. Of greatest utility is the fact that $\left[\mathrm{Rh}(\mathrm{DIP})_{3}\right]^{3+}$ recognizes GU mismatches in RNA within double-helical regions (Chow and Barton, 1992).

Recognition of RNA by $\left[\mathrm{Ru}(\mathrm{TMP})_{3}\right]^{2+}$ and $\left[\mathrm{Ru}(\text { phen })_{3}\right]^{2+}$ (see Basic Protocol 1) is much less informative than by the rhodium complexes. Although one might expect strong binding of $\left[\mathrm{Ru}(\mathrm{TMP})_{3}\right]^{2+}$ to the A-form helices of the RNA, very little selective cleavage is observed. Instead, photolytic cleavage with $\left[\mathrm{Ru}(\mathrm{phen})_{3}\right]^{2+}$ provides a practical and clean chemical $G$ sequencing reaction. Application of $\left[\mathrm{Ru}(\mathrm{phen})_{3}\right]^{2+}$ in this context as a sequencing reagent is therefore described below (see Basic Protocol 6).

In all cases, use of these metal complexes to probe RNA structure is analogous to the experiments described in the previous sections for DNA. Although the types of information the complexes provide are different, the solutions, procedures, and equipment are the same.

\section{BASIC}

PROTOCOL 6

PROTOCOL 6

SUPPORT PROTOCOL 7

Probing Nucleic Acid Structure

\section{SINGLET OXYGEN-MEDIATED CLEAVAGE AT GUANINE RESIDUES IN DNA AND RNA}

The use of $\left[\mathrm{Ru}(\mathrm{phen})_{3}\right]^{2+}$ to control for the shape-selective recognition properties of $\left[\mathrm{Ru}(\mathrm{TMP})_{3}\right]^{2+}$ described in Basic Protocol 5 is not the only use of the complex as a DNA probe. As a result of its nonspecific binding behavior and general oxidative reactivity, $\left[\mathrm{Ru}(\mathrm{phen})_{3}\right]^{2+}$ can also be used as a guanine-specific photosequencing reagent to complement the chemical Maxam-Gilbert methods. By simply applying the protocol described in Basic Protocol 1 to a DNA or RNA of interest, specific and clean determinations of guanine positions in DNA and RNA can be made.

\section{PREPARATION AND LABELING OF DNA AND RNA}

The nucleic acid samples used in studies with these probes have been prepared synthetically using standard solid-phase chemistries or excised from plasmids using restriction endonucleases, or, in the case or RNA, sometimes produced by enzymatic run-off transcription. All samples must be stringently purified either by reversed-phase high-performance liquid chromatography (RP-HPLC) or by PAGE and labeled with ${ }^{32} \mathrm{P}$ on either the $5^{\prime}$ or $3^{\prime}$ end by standard enzymatic methods. Comprehensive protocols for these activities are included elsewhere in this book and in Current Protocols in Molecular Biology, and the reader is directed there for specific details (for nucleic acid synthesis, see Chapter 3 and APPENDIX $3 C$ of this book; for restriction digestion of plasmid DNA, see CPMB UNIT 3.1; for run-off transcription of RNA, see CPMB UNIT 3.8; for purification of restriction fragments, see CPMB UNIT 2.7; for labeling of nucleic acids, see CPMB UNITS 3.5-3.15 and also UNIT 6.1 of this book).

The labeled DNA solution should contain unlabeled, sonicated calf thymus DNA or oligonucleotide DNA (carrier DNA; see below) with enough radiolabeled DNA so that the specific activity of a single irradiation sample is between 20,000 and 200,000 cpm. The appropriate amounts of DNA required are discussed in each Basic Protocol and refer to the amount of carrier DNA, as labeled DNA (on the picomole scale) is assumed not to affect the total DNA concentration. Since photocleavage is performed by mixing DNA and metal complexes at a 1:1 (v/v) ratio, the solution should be made at twice the concentration desired in the photocleavage experiment. Appropriate buffers include ammonium acetate buffer, sodium cacodylate $/ \mathrm{NaCl}$ buffer, Tris/acetate $/ \mathrm{NaCl}$ buffer, Tris/ $\mathrm{NaCl}$ buffer, Tris/NaCl/imidazole buffer (see recipes), and TBE electrophoresis 
buffer (APPENDIX 2A). Concentrated, unlabeled, DNA stock solutions in buffer can be stored refrigerated for several weeks. Solid DNA samples are stable, either refrigerated or frozen, for several months. DNA stocks including radioactivity should be used within one half-life, as longer storage times are associated with larger amounts of nonspecific (background) DNA damage.

Sonicated calf thymus DNA can be obtained commercially and dissolved in an appropriate buffer ( $\mathrm{pH} 7$ to 9). The concentration of a dilution of this stock solution should be determined spectrophotometrically using a value of $13,200 \mathrm{M}^{-1} \mathrm{~cm}^{-1}$ per base pair at 260 $\mathrm{nm}$. The stock solution can then be diluted to a concentration appropriate for its designated use. For oligonucleotides of known sequence, extinction coefficients can be estimated using additive values for each base. One such set of values includes A, 8600; C, 6800; G, 9700 ; and $\mathrm{T}, 8400 \mathrm{M}^{-1} \mathrm{~cm}^{-1}$, and is based on the absorbance characteristics of homopolymers. A more stringent treatment is to make calculations based on each base step in the DNA, as described by Wilson et al. (1997). Once an estimate of the extinction coefficient is made, the concentration of a stock solution can be determined spectrophotometrically and appropriate dilutions can be made.

In the design of an experiment, it is important to consider what will be used as the unlabeled carrier nucleic acid. In most cases this unlabeled nucleic acid is required to increase the concentration of the polymer and ensure good binding of the probe molecule. It is always best that the carrier DNA be of identical sequence to the labeled DNA strand being observed in the experiment. Therefore, in the case of oligonucleotides, extra unlabeled material is simply added to the reaction stocks. Because it is not practical to produce large amounts of plasmid restriction fragments, however, it is not always possible to use DNA of identical sequence as carrier. In that case, another commercially available unlabeled polymer is typically used. The most common alternative is sonicated calf thymus DNA because it is relatively inexpensive. It is important to consider how the selection of a carrier DNA will affect an experiment, however, because the distribution of DNA sites in one sample of DNA is unlikely to be the same as that in a specific labeled restriction fragment. Similar considerations apply to carrier RNA. In the case of run-off transcripts (where only RNA of a single sequence is made), it may be possible to use identical-sequence RNA as carrier. More likely, however, commercially available tRNA will be used as carrier.

\section{PHOTOLYSIS OF METAL COMPLEXES}

Although the exact photolysis procedures that will be successful under any given set of experimental conditions depend on the individual light source used, the following description includes many of the possible options used in the authors' laboratory and is likely to be generally adaptable. It is recommended that a new light system be appropriately tested to ensure that it is performing adequately before attempting any experimental trials. The most straightforward method for performing such tests is the photolysis of commercially available supercoiled plasmid DNA in the presence and absence of the metal complex probes. The results of the photolysis are monitored by agarose gel electrophoresis as described (see Basic Protocol 2). A properly performing lamp system should produce a large fraction of nicked and linearized plasmid DNA in the presence of metal complex and little to no damage in the absence of the probe. If insufficient photocleavage or too much complex-independent damage is observed, the light source must be modified to correct the problems. These modifications include filtering out short-wavelength UV light $(<300 \mathrm{~nm})$, changing the distance between the samples and the light source, and increasing the amount of time the samples are irradiated.
SUPPORT PROTOCOL 8

Chemical and Enzymatic Probes for Nucleic Acid Structure 
After irradiation, nucleic acids can be isolated from the solutions either by drying the samples in a Speedvac evaporator or by ethanol precipitation. It is important to consider the consequences of precipitating DNA when designing a photocleavage experiment and interpreting the results. When DNA is isolated in this manner, the longest polymers are preferentially precipitated. As a result, shorter photocleavage products may be left in the supernatant and discarded. To eliminate this possible complication, it is preferable to dry samples down rather than precipitate them if the electrophoresis of the reactions is not hindered by high salt concentrations or interference of the metal complex (see Critical Parameters and Troubleshooting). Details for precipitation are given in the steps below.

\section{Materials}

Metal complex solution (prepared at twice the concentration desired in the photocleavage experiment; see recipe)

DNA or RNA stock solution containing radiolabeled and unlabeled carrier DNA or RNA (see Support Protocol 7; prepared in buffered solution at twice the desired concentration of all components in the photocleavage experiment)

$9 \mathrm{mM}$ base pairs calf thymus DNA solution in deionized water, buffered to $\mathrm{pH} 7$ to 9 (optional; see Support Protocol 7)

7.5 $\mathrm{M}$ ammonium acetate solution in deionized water (optional)

Absolute ethanol (200 proof, dehydrated; optional)

Dry ice

Loading buffer (e.g., formamide loading buffer or urea loading buffer; see recipes)

1.7- or $0.65-\mathrm{mL}$ silanized microcentrifuge tubes

Light source, such as:

$\mathrm{Hg}$-Xe arc lamp (e.g., Oriel) equipped with an infrared (IR) filter, monochromator, and ultraviolet (UV) cut-off filter $(<300 \mathrm{~nm})$

He-Cd laser (e.g., Linconix model $4200 \mathrm{NB} ; 442 \mathrm{~nm}, 22 \mathrm{~mW}$ )

Transilluminating light box (e.g., Spectroline model TR302 from Spectronics)

with a broad band of irradiation centered at $302 \mathrm{~nm}$

Speedvac evaporator (Savant) or lyophilizer

Liquid scintillation counter

1. Combine equal volumes of metal complex and DNA or RNA stock solutions in a silanized microcentrifuge tube, using a total volume of between 5 and $50 \mu \mathrm{L}$. Agitate the solution well to ensure complete mixing and then centrifuge the solution to the bottom of the tube.

Reactions typically contain between 10,000 and 200,000 cpm of end-labeled nucleic acid fragment. Total nucleic acid concentrations (including unlabeled carrier DNA or RNA) are typically between 5 and $100 \mu \mathrm{M}$ base pairs, depending on the binding constant of the metal complex being used and the desired ratio between the probe and nucleic acid. Additional details for nucleic acid solutions are given in the specific protocols.

2. Set up light and dark control experiments for each nucleic acid and metal complex sample used to ensure the reliability of the experimental results. For dark controls, mix metal complex with nucleic acid as in step 1. For light controls, add the same amount of nucleic acid to the tubes, but add an equal volume of deionized water instead of metal complex.

Dark controls are incubated in the absence of light (i.e., are not irradiated) to assess any nuclease or other contamination. In light controls, nucleic acid is irradiated at the experimental wavelength in the absence of metal complex to measure the level of metal-independent damage. 
3. Allow all samples and controls to equilibrate 5 to $15 \mathrm{~min}$ in the dark at ambient temperature before irradiation.

To ensure consistency throughout an experiment, all samples and controls should be allowed to equilibrate for the same amount of time before irradiation. As a result, if irradiations are being performed serially on a single light source, solutions should be mixed one by one as the experiment progresses.

4. Irradiate samples by positioning the open tubes in the output of a light source for between 5 and $30 \mathrm{~min}$. Place the sample as close as possible to the light source or to the beam focal point of a focused source to maximize exposure to the radiation. After each sample is irradiated, store it in the dark until the experiment is completed.

Typical wavelengths are 313 and $365 \mathrm{~nm}$. The selection of irradiation wavelength is discussed in the individual experimental protocols.

The exact irradiation time is dependent upon the strength of a given light source, the efficiency of the probe, and the wavelength used for irradiation. When a given source or wavelength is first used for an experiment, an irradiation time series should be performed to select the optimum irradiation time. For reference, a given sample irradiated at the focal point of a 313-nm beam produced by a $\mathrm{Hg}$-Xe arc lamp might require 10 min for sufficient cleavage, but require two- or three-fold longer on a transilluminator. The optimal experimental irradiation time consists of the minimal time required to observe a significant level of metal-dependent cleavage. By keeping irradiation as short as possible, metal-independent light damage is minimized.

The lid of the microcentrifuge tube must be open with the light entering through the mouth of the tube. Plastic absorbs strongly at most wavelengths used for these experiments. This requirement also puts an upper constraint on the length of sample irradiation time, as evaporation will occur during the course of photolysis.

5. After irradiation of all samples is completed, dry samples in a Speedvac concentrator (and proceed directly to step 8) or precipitate nucleic acids by adding 1 to $5 \mu \mathrm{L}$ of 9 $\mathrm{mM}$ calf thymus DNA, $1 / 6$ th to $1 / 4$ th vol of $7.5 \mathrm{M}$ ammonium acetate, and 5 vol absolute ethanol. Mix well and incubate on dry ice for $30 \mathrm{~min}$.

For example, for a $25-\mu \mathrm{L}$ sample, add $1 \mu \mathrm{L}$ calf thymus DNA, $5 \mu \mathrm{L}$ ammonium acetate, and $125 \mu$ L absolute ethanol.

Make sure to mix precipitation samples well before chilling on dry ice. If the ethanol and the buffer are not sufficiently combined, the water layer will freeze and no precipitation will occur.

If complete dissociation of the metal complex is desired before electrophoresis, heat the samples 2 min at $90^{\circ} \mathrm{C}$ after addition of the ethanol.

6. Microcentrifuge $12 \mathrm{~min}$ at maximum speed $(14,000 \mathrm{rpm})$.

7. Carefully remove the supernatant, rinse the resulting pellets twice with cold $80 \%$ (v/v) ethanol, and dry under vacuum.

8. Count samples in a liquid scintillation counter and resuspend in loading buffer to a constant concentration of radioactivity before electrophoresis (see Support Protocol 9).

Chemical and Enzymatic Probes for Nucleic Acid Structure 
SUPPORT

PROTOCOL 9
Probing Nucleic Acid Structure

\section{MAPPING CLEAVAGE SITES ON THE NUCLEIC ACID}

The electrophoretic techniques used in identifying nucleic acid cleavage sites are identical to those used in standard DNA sequencing. As a result, the reader is directed to sections of Current Protocols in Molecular Biology for specific procedures (see CPMB UNITS 7.1 \& 7.4 and APPENDIX $3 B$ of this book). In the authors' laboratory, dried or precipitated photocleavage samples are resuspended in denaturing loading buffer (e.g., formamide loading buffer or urea loading buffer; see recipes) and electrophoresed in TBE electrophoresis buffer (APPENDIX $2 A$ ) on $8 \%$ to $20 \%$ (w/v) denaturing polyacrylamide gels cast from commercially available stock solutions (National Diagnostics). The polyacrylamide gel is pre-run until it is warm to the touch. In addition, the samples are heated to $90^{\circ} \mathrm{C}$ for 5 min before loading to promote denaturation of the nucleic acid strands and dissociation of the metal complex probes.

To identify the specific sites of nucleic acid cleavage, photocleavage samples are run alongside samples of the same polymers that have been chemically sequenced using standard MaxamGilbert sequencing reactions (Maxam and Gilbert, 1980; e.g., CPMB UNIT 7.5). Gels are read using standard techniques of autoradiography or phosphorimagery.

Because both Maxam-Gilbert sequencing reactions and metal complex photocleavage result in the loss of a base at the cleavage site, chemical sequencing products comigrate with analogous photocleavage products. Enzymatic sequencing methods, which do not involve base loss, will result in a systematic one-base shift in the positioning of the cleavage bands.

\section{REAGENTS AND SOLUTIONS}

Use deionized, distilled water in all recipes and protocol steps. For common stock solutions, see APPENDIX 2A; for suppliers, see SUPPLIERS APPENDIX.

\section{Ammonium acetate buffer, $10 \times$}

$19.3 \mathrm{~g} / \mathrm{L}$ ammonium acetate $(250 \mathrm{mM})$

Adjust to $\mathrm{pH} 9$ with $\mathrm{NH}_{4} \mathrm{OH}$ and acetic acid

Sterilize by filtering with a $0.22-\mu \mathrm{m}$ filter

Store up to several months at room temperature

\section{Formamide loading buffer}

$80 \%(\mathrm{v} / \mathrm{v})$ deionized formamide

$50 \mathrm{mM}$ Tris base

$50 \mathrm{mM}$ boric acid

$1 \mathrm{mM}$ EDTA

$0.025 \%(\mathrm{w} / \mathrm{v})$ xylene cyanol

$0.025 \%(\mathrm{w} / \mathrm{v})$ bromphenol blue

Adjust to $\mathrm{pH} 8.3$

Store for up to several months at room temperature

In the authors' experience, this buffer performs better than the urea loading buffer for resuspending samples after drying or precipitation.

\section{Metal complex solution}

Prepare all metal complex solutions as concentrated stocks in deionized water from a sample of solid reagent immediately before use. Determine the concentration of the stock solution spectrophotometrically using the extinction coefficients provided in the Commentary (see Compound Characterization) and then make dilutions in deionized water to concentrations appropriate for the experiments. Store solutions in the dark for the duration of a single experiment and discarded immediately after use. 
Sodium cacodylate/NaCl buffer, 10×

$15.9 \mathrm{~g} / \mathrm{L}$ sodium cacodylate $(100 \mathrm{mM})$

$23.4 \mathrm{~g} / \mathrm{L}$ sodium chloride $(400 \mathrm{mM})$

Adjust to $\mathrm{pH} 7$ with $\mathrm{NaOH}$ and cacodylic acid

Sterilize by filtering with a $0.22-\mu \mathrm{m}$ filter

Store up to several months at room temperature

Tris/acetate buffer, 10×

Prepare as for Tris/acetate/ $\mathrm{NaCl}$ buffer (see recipe) but omit $\mathrm{NaCl}$.

Tris/acetate/NaCl buffer, 10×

$60.6 \mathrm{~g} / \mathrm{L}$ Tris base $(500 \mathrm{mM})$

$16.4 \mathrm{~g} / \mathrm{L}$ sodium acetate $(200 \mathrm{mM})$

$10.5 \mathrm{~g} / \mathrm{L}$ sodium chloride $(180 \mathrm{mM})$

Adjust to $\mathrm{pH} 7$ with $\mathrm{NaOH}$ and acetic acid

Sterilize by filtering with a $0.22-\mu \mathrm{m}$ filter

Store up to several months at room temperature

Tris/NaCl buffer, 10×

$6.1 \mathrm{~g} / \mathrm{L}$ Tris base $(50 \mathrm{mM})$

$29.2 \mathrm{~g} / \mathrm{L}$ sodium chloride $(500 \mathrm{mM})$

Adjust to $\mathrm{pH} 7$ with $\mathrm{NaOH}$ and $\mathrm{HCl}$

Sterilize by filtering with a $0.22-\mu \mathrm{m}$ filter

Store up to several months at room temperature

Tris/NaCl/imidazole buffer, 10×

$6.1 \mathrm{~g} / \mathrm{L}$ Tris base $(50 \mathrm{mM})$

$29.2 \mathrm{~g} / \mathrm{L}$ sodium chloride $(500 \mathrm{mM})$

$0.82 \mathrm{~g} / \mathrm{L}$ imidazole $(12 \mathrm{mM})$

Adjust to $\mathrm{pH} 7$ with $\mathrm{NaOH}$ and $\mathrm{HCl}$

Sterilize by filtering with a $0.22-\mu \mathrm{m}$ filter

Store up to several months at room temperature

\section{Urea loading buffer}

$7 \mathrm{M}$ urea

$90 \mathrm{mM}$ Tris base

$90 \mathrm{mM}$ boric acid

$2.5 \mathrm{mM}$ EDTA

$0.025 \%(\mathrm{w} / \mathrm{v})$ xylene cyanol

$0.025 \%(\mathrm{w} / \mathrm{v})$ bromphenol blue

Adjust to $\mathrm{pH} 8.3$

Store for up to several months at room temperature

Refrigeration of this buffer is not recommended as the urea tends to crystallize out. In the authors' experience, the formamide-based buffer performs better for resuspending samples after drying or precipitation.

\section{COMMENTARY}

\section{Background Information}

Recent results in NMR structure determination and X-ray crystallography of nucleic acids (Hartmann and Lavery, 1996) have shown that the structure of correctly matched, putatively canonical B-form DNA can be heterogeneous and polymorphic. When the additional helical forms and the many possible DNA lesions (e.g., mismatches, bulges, abasic sites, DNA-drug adducts, and sites of base damage) are added, it is clear that what was once thought to be an uninteresting linear polymer can hide a wealth of structural variety. When the field of consideration is expanded to include RNA, whose
Chemical and Enzymatic Probes for Nucleic Acid Structure 
folding pathways and structures rival those of proteinsincomplexity, and the many heteroduplexes that now exist between DNA and other polymers, the structural determinations of nucleic acids becomes a very rich field indeed.

Because of the time and resources that are involved in techniques for high-resolution structural determination, solution probes of nucleic acids have a very important role in the pursuit of a broad-based structural understanding of DNA and RNA. Unhindered by the concerns of size and system selection that sometimes make NMR difficult, and the need for crystals to determine a structure in the solid state, photochemical probes like those described here provide a rapid, relatively inexpensive method to probe the characteristics of DNA or RNA in solution. Furthermore, for larger macromolecules in particular, chemical probe studies can serve as a bridge to high-resolution structural information.

The specific transition metal complex probes described in this unit therefore help fill a critical niche in the large body of chemical and photochemical probes for nucleic acid structure. Residing between probes that have been designed to identify specific sequences along a DNA or RNA strand or helix and the large body of chemical probes that cleave nucleic acids more nonspecifically at primarily solvent-accessible sites, it is the structure specificity of these complexes that makes them unique. The three-dimensional shapes of the complexes, which lead to their structural recognition properties, allow the identification of specific geometries without consideration of base sequence.

One of the most well-defined rhodium complexes that has been used for a wide variety of purposes, $\left[\mathrm{Rh}(\mathrm{phen})_{2}(\mathrm{phi})\right]^{3+}$, binds in the major groove of DNA by intercalation of the phi ligand between adjacent base pairs (Pyle et al., 1989). DNA strand cleavage is effected by direct hydrogen atom abstraction by the photoexcited phi ligand at the site of intercalation (Sitlani et al., 1992). The complex recognizes primarily two families of sites: $5^{\prime}$-pyrimidinepyrimidine-purine-purine- $3^{\prime}$ and homopyrimidine-homopurine tracts. The two enantiomers of the complex demonstrate different recognition behaviors. The $\Delta$ enantiomer, whose chirality is complementary to the right-handed DNA helix, favors the pyrimidine-pyrimidinepurine-purine tracts (Sitlani and Barton, 1994). Site selectivity of this complex is based on shape selection by the bulky aromatic phenanthroline ligands. Comparisons of crystallographic data on the sequences targeted by the complex show that they are more open in the major groove, thus allowing both the stacking, intercalative interactions of the phi ligand and accommodation of the phen ancillary ligands. Enantioselectivity in cleavage correlates with the opening of sites and changes in the propeller twisting of the bases involved (Campisi et al., 1994). When $\left[R h(p h e n)_{2}(\text { phi) }]^{3+}\right.$ is applied to ribonucleic acids, the folding of complex RNA molecules can be assessed; in an application that crosses over the boundaries between the two types of nucleic acids, the same complex has been used to examine the structure of tDNA $^{\text {Phe }}$ (the DNA analog of tRNA ${ }^{\text {Phe }}$ ) to assess the similarities or differences between DNA copies and their RNA counterparts (Lim and Barton, 1993).

The other molecule used as a geometrical probe of unknown DNA sequences, $\left[\mathrm{Ru}(\mathrm{TMP})_{3}\right]^{2+}$, has very different behavior. It does not bind by intercalation but rather to the surface of the minor groove of DNA. The complex binds avidly to $\mathrm{A}$-form helices and exhibits little binding to B- or Z-form synthetic oligonucleotides. There is some level of chiral discrimination in binding that favors the $\Lambda$-isomer of the complex (Mei and Barton, 1986). The basis of the binding selectivity of $\left[\mathrm{Ru}(\mathrm{TMP})_{3}\right]^{2+}$, like $\left[\mathrm{Rh}(\mathrm{phen})_{2}(\mathrm{phi})\right]^{3+}$, rests in shape selection, although in this case generated by a different type of interaction. The sterically bulky methyl groups on the TMP ligands not only prevent intercalation, which is observed for the unmethylated $\left[\mathrm{Ru}(\text { phen })_{3}\right]^{2+}$ parent complex, but also restrict binding to open and shallow areas of the minor groove. This explains the preferential binding to A-form DNA and RNA by $\left[\mathrm{Ru}(\mathrm{TMP})_{3}\right]^{2+}$. In contrast to the direct photocleavage found with $\left[\mathrm{Rh}(\mathrm{phen})_{2}(\mathrm{phi})\right]^{3+}$, where the cleavage chemistry involves reaction with the deoxyribose sugar and shows no sequence bias, irradiation of the ruthenium complexes sensitizes the formation of singlet oxygen, a diffusible species that reacts with nearby bases and preferentially with guanine residues (Mei and Barton, 1988). As a result, $\left[\mathrm{Ru}(\mathrm{TMP})_{3}\right]^{2+}$ cleavage must be compared with $\left[\operatorname{Ru}(\text { phen })_{3}\right]^{2+}$, its sequence-neutral analog, to deduce areas of preferential TMP binding. The combination of $\left[\mathrm{Rh}(\mathrm{phen})_{2}(\mathrm{phi})\right]^{3+}$ and $\left[\mathrm{Ru}(\mathrm{phen})_{3}\right]^{2+}$ probes have been applied to mapping the conformation of DNA within an entire gene (Huber et al., 1991).

The shape and structure specificity that is provided by simple steric exclusion has also been used for a variety of recognition tasks. The ability of $\left[\mathrm{Rh}(\mathrm{DIP})_{3}\right]^{3+}$ to recognize cruciforms 
and other unusual tertiary structures is a relatively unique property that has been comprehensively explored in the authors' laboratory. Experiments have shown that it is the cruciform structure, rather than any specific sequence, that is targeted by the molecule (Kirshenbaum et al., 1988). The molecule's shape selectivity has also been applied to an examination of the DNA structures in the SV40 T antigen and adenovirus 2 E1A genes (Lee and Barton, 1993). This steric specificity mechanism has been applied to the design of the intercalating ligand $\left[\mathrm{Rh}(\text { bpy })_{2} \text { (chrysi) }\right]^{3+}$, which has been used to probe both the structures of DNA base mismatches (Jackson and Barton, 1997; Jackson et al., 1999) and abasic sites in DNA (B.A. Jackson and J.K. Barton, unpub. observ.). A comprehensive study of this molecule and its recognition behavior is currently in progress in the authors' laboratory.

When these probes are used to examine RNA structure, their unique properties lead to additional applications. From the studies performed on tRNA ${ }^{\text {Phe }}$, the authors' laboratory has shown that the A-form configuration of RNA leads to much more specific recognition of ribonucleic acid structural features by this family of rhodium probes. The complex recognizes sites of tertiary structure, including bulges and triplex sites where the phi intercalating ligand can gain access to the major groove of the nucleic acid. It is becoming clear that RNA binding proteins also target sites that are opened in the major groove. As a result, use of $\left[\mathrm{Rh}(\mathrm{phen})_{2}(\mathrm{phi})\right]^{3+}$ may find application in scanning unknown ribonucleic acids for possible protein-binding sites. The cleavage behavior of $\left[\mathrm{Rh}(\mathrm{phen})_{2}(\mathrm{phi})\right]^{3+}$ has been used to examine structural domains in eukaryotic $5 \mathrm{~S}$ rRNA (Chow et al., 1992) and to probe the conformations of TAR RNAs from human (Neenhold and Rana, 1995) and bovine (Lim and Barton, 1997) immunodeficiency viruses.

Moving away from modes of structural recognition, the nonspecific $\left[\mathrm{Rh}(\mathrm{phi})_{2}(\mathrm{bpy})\right]^{3+}$ complex is an important addition to the body of molecular tools for studying the interactions between DNA and other molecules. Because its DNA cleavage chemistry is photoinduced, it provides a unique opportunity to study systems where it is advantageous to combine all the components at one time and activate the footprinting reaction later. This compound has been used in the authors' laboratory to footprint both DNA-binding proteins (like EcoRI) and small DNA binders (like distamycin; Uchida et al., 1989). Furthermore, $\left[\mathrm{Rh}(\mathrm{phi})_{2}(\mathrm{bpy})\right]^{3+}$ is unaffected by additives such as glycerol and $\mathrm{Mg}^{2+}$ at the levels that might be required to promote DNA binding by certain proteins. It can footprint both major and minor groove ligands, and, since no diffusible intermediate is involved in the cleavage, produces sharp, wellresolved footprint patterns.

In spite of the breadth and number of tasks to which these reagents have been applied in the past, the many open questions about nucleic acid structure provide myriad opportunities where solution probes like those described here can be used. As recent crystal structures of DNA-protein complexes have made clear, the shape and geometry of a nucleic acid target site can play an instrumental role in specific DNAprotein interactions. As more is discovered about the unique structures of damaged or mispaired sites in DNA and the dramatic effects that DNA-binding proteins and small molecules can have on DNA geometry, the easily accessible information that can be provided by solution probes of structure becomes more and more valuable.

\section{Compound Characterization}

\section{Mapping DNA major and minor groove characteristics}

\section{$\left[\mathrm{Rh}(\text { phen })_{2}\left(\mathrm{Cl}_{2}\right)\right] \mathrm{Cl}$}

${ }^{1} \mathrm{H}-\mathrm{NMR}: \mathrm{d}_{6}$-dmso, $9.69(\mathrm{~d}, 2 \mathrm{H}) ; 8.99(\mathrm{~d}$, $2 \mathrm{H}) ; 8.89(\mathrm{~d}, 2 \mathrm{H}) ; 8.62(\mathrm{t}, 2 \mathrm{H}) ; 8.32(\mathrm{t}, 2 \mathrm{H})$; $8.18,(\mathrm{t}, 2 \mathrm{H}) ; 7.80(\mathrm{~d}, 2 \mathrm{H}) ; 7.59$ (t, 2H).

\section{$\left[\mathrm{Rh}(\text { phen })_{2}\left(\mathrm{NH}_{3}\right)_{2}\right] \mathrm{Cl}_{3}$}

${ }^{1} \mathrm{H}$-NMR: $\mathrm{d}_{6}$-acetone, $9.93(\mathrm{~d}, 2 \mathrm{H}) ; 9.42(\mathrm{~d}$, $2 \mathrm{H}) ; 8.99(\mathrm{~d}, 2 \mathrm{H}) ; 8.64(\mathrm{~m}, 4 \mathrm{H}) ; 8.51(\mathrm{~d}, 2 \mathrm{H})$; $8.32(\mathrm{~d}, 2 \mathrm{H}) ; 7.87$ (dd, 2H); 5.18 (broad s, 6H).

${ }^{13} \mathrm{C}-\mathrm{NMR}: \mathrm{d}_{6}$-acetone, $154.1,153.6,147.6$ q, 146.6 q, 142.9, 141.5, 133.2 q, 129.2, 129.1, 128.3, 127.7.

$\mathrm{UV} / \mathrm{visible}$ (acetonitrile/water 1:1, $1.9 \times 10^{-}$ $\left.{ }^{5} \mathrm{M}\right): \varepsilon_{302}, 12,400 \mathrm{M}^{-1} \mathrm{~cm}^{-1}, \varepsilon_{271}, 51,500 \mathrm{M}^{-1}$ $\mathrm{cm}^{-1}, \varepsilon_{222}, 51,800 \mathrm{M}^{-1} \mathrm{~cm}^{-1}$.

\section{$[\text { Rh(phen })_{2}($ phi $\left.)\right] C l_{3}$}

${ }^{1} \mathrm{H}-\mathrm{NMR}$ : $\mathrm{d}_{6}$-dmso, 14.98 (s, N-H phi); 9.25 (d, H 4 phen); 9.12 d, H 2 phen); 9.03 (d, H 7 phen); 8.94 (d, H 5,6 phen); 8.54 (dd, H 4,5 phi); 8.47 (d, H 1,8 phi); 8.36 (dd, H 3 phen); 8.08 (d, H 9 phen); 7.91 (dd, H 8 phen); 7.84 (t, H 2,7 phi); 7.57 (t, H 3,6 phi).

UV/visible: $\varepsilon_{362}, 19,400 \mathrm{M}^{-1} \mathrm{~cm}^{-1}(\mathrm{pH}$ isosbestic point); $\varepsilon_{358}, 19,400 \mathrm{M}^{-1} \mathrm{~cm}^{-1} ; \varepsilon_{300}$, $34,000 \mathrm{M}^{-1} \mathrm{~cm}^{-1} ; \varepsilon_{272}, 116,200 \mathrm{M}^{-1} \mathrm{~cm}^{-1}$.
Chemical and Enzymatic Probes for Nucleic Acid Structure 
CD: ( $\Delta$ enantiomer, acetonitrile, $1.47 \times 10^{-5}$ M) 261 (99), 275 (-179), 346 (-24).

\section{$\left[\mathrm{Ru}(\mathrm{TMP})_{3}\right] \mathrm{Cl}_{2}$}

${ }^{1} \mathrm{H}-\mathrm{NMR}: \mathrm{CDCl}_{3}, 8.20$ (s, H 5,6); 7.98 (s, $\mathrm{H}, 2,9) ; 2.74$ (s, $\left.\mathrm{CH}_{3}, 4,7\right) ; 2.37$ (s, $\left.\mathrm{CH}_{3}, 3,8\right)$.

UV/visible: $\varepsilon_{210}, 94,500 \mathrm{M}^{-1} \mathrm{~cm}^{-1} ; \varepsilon_{233}$, $64,000 \mathrm{M}^{-1} \mathrm{~cm}^{-1} ; \varepsilon_{269}, 114,600 \mathrm{M}^{-1} \mathrm{~cm}^{-1}$; $\varepsilon_{299 \text { (shoulder) }}, 26,400 \mathrm{M}^{-1} \mathrm{~cm}^{-1} ; \varepsilon_{438}, 24,500 \mathrm{M}^{-1}$ $\mathrm{cm}^{-1}$.

\section{[Ru(phen) $\left.{ }_{3}\right] \mathrm{Cl}_{2}$}

${ }^{1} \mathrm{H}-\mathrm{NMR}: \mathrm{d}_{6}$-dmso, 8.8 (d, H 4,7); 8.7 (d, H 2,9); 8.4 (s H 5,6); 7.7 (dd, H 3,8).

UV/visible: $\varepsilon_{222}, 87,600 \mathrm{M}^{-1} \mathrm{~cm}^{-1} ; \varepsilon_{262}$, $107,000 \mathrm{M}^{-1} \mathrm{~cm}^{-1} ; \varepsilon_{291(\text { shoulder) }}, 22,500 \mathrm{M}^{-1}$ $\mathrm{cm}^{-1} ; \varepsilon_{447}, 19,000 \mathrm{M}^{-1} \mathrm{~cm}^{-1}$.

\section{Shape-selective cleavage of unusual structures in nucleic acids}

\section{$\left[\mathrm{Rh}(\mathrm{DIP})_{3}\right] \mathrm{Cl}_{3}$}

${ }^{1} \mathrm{H}-\mathrm{NMR}: \mathrm{CDCl}_{3}, 9.01(\mathrm{~d}, 6 \mathrm{H}) ; 8.30(\mathrm{~s}, 6 \mathrm{H})$; $8.07(\mathrm{~s}, 6 \mathrm{H}) ; 7.71-7.69(\mathrm{~m}, 10 \mathrm{H}) ; 7.61-7.53(\mathrm{~m}$, 20H).

UV/visible: $\varepsilon_{296}, 116,000 \mathrm{M}^{-1} \mathrm{~cm}^{-1}$; $\varepsilon_{334 \text { (shoulder) }}, 49,200 \mathrm{M}^{-1} \mathrm{~cm}^{-1} ; \varepsilon_{370}, 19,400 \mathrm{M}^{-1}$ $\mathrm{cm}^{-1}$.

\section{Recognition of destabilized structures in DNA}

\section{5,6-chrysenequinone}

${ }^{1} \mathrm{H}-\mathrm{NMR}: \mathrm{CD}_{2} \mathrm{Cl}_{2}, 9.39(\mathrm{~d}, 1 \mathrm{H}) ; 8.16(\mathrm{~m}$, $4 \mathrm{H}) ; 7.92(\mathrm{~d}, 1 \mathrm{H}) ; 7.77(\mathrm{t}$ of d, $2 \mathrm{H}) ; 7.57$ ( $\mathrm{t}$ of $\mathrm{d}, 2 \mathrm{H})$.

\section{[Rh(bpy) $\left.2\left(\mathrm{Cl}_{2}\right)\right] \mathrm{Cl}$}

${ }^{1} \mathrm{H}-\mathrm{NMR}: \mathrm{d}_{6}$-dmso, 9.69 (d, 2H); 9.0 (d, $2 \mathrm{H}) ; 8.89(\mathrm{~d}, 2 \mathrm{H}) ; 8.63(\mathrm{t}, 2 \mathrm{H}) ; 8.33(\mathrm{t}, 2 \mathrm{H})$; $8.17(\mathrm{t}, 2 \mathrm{H}) ; 7.80(\mathrm{~d}, 2 \mathrm{H}) ; 7.59(\mathrm{t}, 2 \mathrm{H})$.

\section{$\left[\mathrm{Rh}(\text { bpy })_{2}(\mathrm{NH} 3)_{2}\right] \mathrm{Cl}_{3}$}

${ }^{1} \mathrm{H}-\mathrm{NMR}$ : $\mathrm{d}_{6}$-acetone, $9.45(\mathrm{~d}, 2 \mathrm{H}) ; 9.05$ (d, $2 \mathrm{H}) ; 8.89(\mathrm{~d}, 2 \mathrm{H}) ; 8.79(\mathrm{td}, 2 \mathrm{H}) ; 8.45(\mathrm{td}, 2 \mathrm{H})$; $8.30(\mathrm{td}, 2 \mathrm{H}) ; 8.05(\mathrm{~d}, 2 \mathrm{H}) ; 7.74(\mathrm{td}, 2 \mathrm{H}) ; 5.06$, (broad s, 6H).

\section{[Rh(bpy) 2 (chrysi)]Cl3}

${ }^{1} \mathrm{H}-\mathrm{NMR}: \mathrm{CD}_{3} \mathrm{OD}, 8.94(\mathrm{t}, 2 \mathrm{H}) ; 8.86(\mathrm{t}, 2 \mathrm{H})$; $8.80(\mathrm{~d}, 1 \mathrm{H}) ; 8.77(\mathrm{~d}, 1 \mathrm{H}) ; 8.56($ split t, $2 \mathrm{H})$; $8.44(\mathrm{~m}, 5 \mathrm{H}) ; 8.40(\mathrm{~d}, 1 \mathrm{H}) ; 8.15(\mathrm{~m}, 1 \mathrm{H}) ; 8.03$ $(\mathrm{m}, 1 \mathrm{H}) ; 7.95,(\mathrm{~m}, 3 \mathrm{H}) ; 7.86,(\mathrm{~d}, 1 \mathrm{H}) ; 7.81,(\mathrm{~d}$, 1H); 7.64, (m, 5H).

${ }^{13} \mathrm{C}-\mathrm{NMR}: \mathrm{CD}_{3} \mathrm{OD}, 183.3,177.3,175.4$, 157.4, 157.2, 157.2, 153.8, 153.2, 152.1, 144.6, $144.5,143.9,143.8,139.7,138.8,138.4,136.2$,
135.7, 132.3, 132.2, 132.0, 131.8, 130.9, 130.8, 130.6, 130.2, 129.4, 127.7, 127.6, 127.3, 126.9, 126.8, 123.9, 122.9, 120.8, 118.6, 116.3, 114.1.

UV/visible (water, $7.8 \times 10^{-6} \mathrm{M}$ ): $\varepsilon_{271}$, $63,800 \mathrm{M}^{-1} \mathrm{~cm}^{-1}$ (pH isosbestic point); $\varepsilon_{303}$, $57,000 \mathrm{M}^{-1} \mathrm{~cm}^{-1} ; \varepsilon_{315}, 52,200 \mathrm{M}^{-1} \mathrm{~cm}^{-1} ; \varepsilon_{391}$, $10,600 \mathrm{M}^{-1} \mathrm{~cm}^{-1}$.

\section{Photofootprinting of DNA-binding molecules}

\section{$\left[\mathrm{Rh}(\mathrm{phi})_{2} \mathrm{Cl}_{2}\right] \mathrm{Cl}$}

${ }^{1} \mathrm{H}-\mathrm{NMR}: \mathrm{d}_{6}$-dmso, trans product: 14.89 (s, $4 \mathrm{H}) ; 8.75(\mathrm{~d}, 4 \mathrm{H}) ; 8.53(\mathrm{~d}, 4 \mathrm{H}) ; 7.92(\mathrm{t}, 4 \mathrm{H})$; $7.82(\mathrm{t}, 4 \mathrm{H})$; cis product, $14.53(\mathrm{~s}, 2 \mathrm{H}) ; 13.19$ $(\mathrm{s}, 2 \mathrm{H}) ; 9.23(\mathrm{~d}, 2 \mathrm{H}) ; 8.5(\mathrm{t}, 4 \mathrm{H}) ; 8.37(\mathrm{~d}, 2 \mathrm{H})$; $7.95(\mathrm{~d}, 2 \mathrm{H}) ; 7.8(\mathrm{~d}, 2 \mathrm{H}) ; 7.75(\mathrm{t}, 2 \mathrm{H}) ; 7.58(\mathrm{t}$, $2 \mathrm{H})$.

\section{$[R h(p h i) 2(b p y)] C l_{3}$}

${ }^{1} \mathrm{H}-\mathrm{NMR}: \mathrm{d}_{6}$-dmso, $14.13(\mathrm{~s}, 2 \mathrm{H}, \mathrm{N}-\mathrm{H})$; 13.63 (s, 2H, N-H); 8.92 (d, 2H); $8.66(\mathrm{~m}, 6 \mathrm{H})$; $8.45(\mathrm{~d}, 6 \mathrm{H}) ; 7.84(\mathrm{~m}, 6 \mathrm{H}) ; 7.61(\mathrm{t}, 4 \mathrm{H})$.

UV/visible (Tris-acetate, $\mathrm{pH} 7.0$ ): $\varepsilon_{250}$, $67,400 \mathrm{M}^{-1} \mathrm{~cm}^{-1} ; \varepsilon_{262}, 62,400 \mathrm{M}^{-1} \mathrm{~cm}^{-1} ; \varepsilon_{270}$, $64,200 \mathrm{M}^{-1} \mathrm{~cm}^{-1} ; \varepsilon_{292}, 43,200 \mathrm{M}^{-1} \mathrm{~cm}^{-1} ; \varepsilon_{312}$, $30,000 \mathrm{M}^{-1} \mathrm{~cm}^{-1} ; \varepsilon_{378}, 28,200 \mathrm{M}^{-1} \mathrm{~cm}^{-1} ; \varepsilon_{350}$, $23,600 \mathrm{M}^{-1} \mathrm{~cm}^{-1}$ (pH isosbestic point).

\section{Critical Parameters and Troubleshooting}

\section{Syntheses of transition metal probes}

Other than the general safety concerns involved with working with flammable liquids and strong acids, most of the synthetic work described in this unit has few concerns. In those reactions that require vacuum lines and evacuation of glassware, care must be taken to select equipment that can withstand the required changes in pressure, and appropriate protective eyewear and a laboratory coat should be worn. All reactions, even those that do not specifically mention it, should be performed in a well-functioning fume hood whenever possible. In the authors' hands, the reactions described in this work have performed to produce their intended products in reliable yields. In all cases, if a reaction is not performing as it should, the correct course of action is to assess the identity and purity of all starting materials and reagents and try the reaction again.

\section{DNA photocleavage experiments}

To achieve success with any of the protocols for assaying DNA structure, all reagents must be of the highest possible purity. The DNA or 
RNA fragments in use must be scrupulously purified. In the case of restriction fragments and RNA transcripts, the nucleic acids must be purified by polyacrylamide gel electrophoresis, and the smallest possible gel band containing the labeled fragment should be excised from the gel. After the labeled polymer is removed from the gel, it must be purified from the various components that were present in the electrophoresis buffers. This should be done by ethanol precipitation or by using one of the many commercially available reversed-phase purification cartridges. In the case of synthetic oligonucleotides, the synthesized materials must be purified by HPLC and, after end labeling, also purified by either denaturing or nondenaturing PAGE. In the authors' laboratory, the last trityl protecting group is typically left at the end of DNA synthesis and used as a hydrophobic handle for HPLC purification. After removing the protecting group, a second HPLC run is performed to ensure purity. In both cases, only the top portion of the major product peak is collected. If an experiment is run with insufficiently pure nucleic acid, the most obvious symptom is an absence of clear, clean banding in all experimental lanes. Such behavior will also be observed in the Maxam-Gilbert sequencing reactions.

The metal complexes used for photolysis reactions must also be of the highest possible purity. If they are contaminated by synthetic side products or other material, the concentrations of prepared solutions will be incorrect and other reactivity (unrelated to the desired rhodium or ruthenium probe) may be observed. It is customary in the authors' laboratory to HPLC purify all metal complexes after ion-exchange chromatography or enantiomer resolution to ensure their purity. If desired, enantiomeric purity can be verified by $\mathrm{CD}$ spectroscopy or by use of a commercially available chiral HPLC column. Furthermore, even if metal solutions are made from analytically pure material, it is critical that the solutions used in photocleavage be made as close as possible to the time the experiments are performed. With extended storage in solution, especially with exposure to light, the various metal complex probes can degrade. The degradation products may interact with or cleave DNA, with different specificities than that of the intended probes.

All buffer solutions should be made with the highest purity materials available, treated carefully to ensure continuing purity, and remade frequently. In the authors' laboratory it is also customary to filter all solutions through 0.22 - $\mu \mathrm{m}$ sterilizing filter units before use. Nuclease contamination in buffers can occur through environmental factors and can result in observed cleavage that is independent of irradiation. This is of particular concern with work relating to RNA. Other contaminants in stock solutions can lead to light-dependent damage to the target DNA as well.

All the concerns regarding reagent and solution purity underscore the importance of running control samples as part of each photocleavage experiment. These must include both dark controls (DNA incubated with a metal complex probe in the absence of light) and light controls (DNA irradiated in the absence of metal complex). Without these important comparisons, it is impossible to assess the value of any given experimental result. Furthermore, even with the best techniques and intentions, single samples sometimes become contaminated and give anomalous results. This underscores the importance of repeating trials when experimental or control samples display unexpected behavior.

Depending on the light source that is available for metal complex irradiation and the specific experimental plan, some troubleshooting of each new system must be done to obtain optimal results with these DNA probes. In all cases, if insufficient cleavage is observed in a given experiment, appropriate responses are to increase the concentrations of the complexes and DNA to promote more complete binding, increase the irradiation times for the experimental samples, and, depending on the sensitivity of the autoradiography technique being employed, increase the amount of radioactivity loaded in each gel lane. On the other hand, if too much photocleavage is observed, one can no longer trust the data extracted from a DNA photocleavage experiment, because at high levels of cleavage there is no reasonable guarantee that single-hit conditions prevail (i.e., that each cleaved polymer has been cut only once by a single metal complex). In the authors' laboratory, excessive cleavage is defined as an experiment where $>10 \%$ of the full-length polymer has been cleaved. Under multiple-hit conditions, cleavage bands that correspond to shorter polymers will be enriched at the expense of longer cleavage products. In this case, the exact opposite course of action is required as when too little cleavage is observed (reduce metal complex concentration or decrease irradiation times).

In addition to these general concerns for all photocleavage protocols, a few procedures
Chemical and Enzymatic Probes for Nucleic Acid Structure 


\begin{tabular}{|c|c|}
\hline Problem & Possible cause \\
\hline $\begin{array}{l}\text { Gels do not show clean banding, } \\
\text { including in Maxam-Gilbert } \\
\text { sequencing lanes }\end{array}$ & $\begin{array}{l}\text { Contamination of desired labeled DNA by } \\
\text { fragments or shorter oligonucleotide } \\
\text { synthetic products produces labeled DNA } \\
\text { sample of heterogeneous length }\end{array}$ \\
\hline $\begin{array}{l}\text { Unexpected cleavage bands } \\
\text { observed in experimental lanes but } \\
\text { not light or dark controls }\end{array}$ & $\begin{array}{l}\text { Damage is dependent on the addition of the } \\
\text { metal solution and irradiation. Likely } \\
\text { contamination of the metal solution by a } \\
\text { synthetic by-product or breakdown product }\end{array}$ \\
\hline \multirow[t]{2}{*}{$\begin{array}{l}\text { Unexpected cleavage bands } \\
\text { observed in experimental samples } \\
\text { and light control but not dark control }\end{array}$} & $\begin{array}{l}\text { Likely cause is a contaminant in one of the } \\
\text { buffer solutions or solvents used in making } \\
\text { up the experimental samples that causes } \\
\text { light-induced damage to the nucleic acid. }\end{array}$ \\
\hline & $\begin{array}{l}\text { This behavior has also been observed when } \\
\text { nonsilanized tubes are used for irradiation } \\
\text { reactions. Presumably some component in } \\
\text { the plastic leaches into solution in sufficient } \\
\text { concentration to promote light-induced } \\
\text { DNA damage }\end{array}$ \\
\hline
\end{tabular}

Unexpected cleavage bands observed in experimental lanes and dark control but not light control

Unexpected cleavage bands observed in experimental lanes, dark control, and light control

Damage observed in dark control that is similar to experimental lanes

Smearing observed in experimental lanes but not in sequencing or light control

Bands of interest too high or low on Gel run for inappropriate time the gel for adequate clarity

Band intensity varies dramatically from gel lane to gel lane, specifically in the uncleaved DNA band nuclease of some type ambient lighting nucleic acids amount of radioactivity
Damage is dependent on addition of metal solution but not on irradiation. Likely cause is contamination of the metal solution by a

Likely cause is contamination of DNA stock Prepare fresh DNA and metal (or buffer/water stocks) by a nuclease that cleaves DNA independent of irradiation

Likely due to exposure of dark control to

Most likely due to problems with renaturation of nucleic acid strands or interaction between the metal complex and

Gel lanes were not loaded with the same
Purify DNA more stringently before running the experiment to ensure homogeneity

Purify metal complex again by ion exchange or HPLC

Prepare fresh buffer solutions and stocks from new materials of known purity

Use silanized microcentrifuge tubes

Prepare fresh metal solutions from new materials of known purity solutions from new materials of known purity

Keep samples dark before and after irradiation

Heat samples to $90^{\circ} \mathrm{C}(5 \mathrm{~min})$ before loading gel and pre-run the gel until very hot to ensure strand denaturation. If necessary, reprecipitate samples to remove metal complex.

Run gel longer or shorter to affect position of bands in gel. For best resolution of cleaved bases and different polymer ends, bands of interest should be in the lower third of the gel.

Ensure samples are resuspended well and at the same concentration of radioactivity

continued 


\begin{tabular}{ll}
\hline Problem & \multicolumn{1}{c}{ Possible cause } \\
\hline $\begin{array}{l}\text { As bands progress down the gel, } \\
\text { they compress towards the center of } \\
\text { the lane or run anomalously }\end{array}$ & $\begin{array}{l}\text { High concentrations of salt in samples } \\
\text { loaded on the gel can affect the mobility of } \\
\text { thempared to Maxam-Gilbert } \\
\text { sequencing reactions }\end{array}$
\end{tabular}

Insufficient DNA cleavage observed Concentration may be too low for effective in experimental lanes

Too much cleavage, resulting in $>10 \%$ depletion of the full-length DNA band binding of complexes to DNA

Ratio of total DNA concentration to the metal complex probe may be too high to cleave an observable fraction of the labeled DNA

Light source may be too weak to promote enough DNA cleavage

Amount of radioactivity loaded per gel lane may be too low for sensitivity of the autoradiography technique

Too much metal complex in the reaction for a given reaction time, resulting in extensive cleavage. This will likely involve more than one cleavage event per DNA polymer making the data unreliable
Reduce the effect/amount of loaded salt by: (1) precipitating samples with ammonium acetate and drying thoroughly under vacuum, (2) increasing the amount of radioactivity in each irradiation sample so a smaller fraction of the sample is loaded on the gel, (3) running the gel at a very low wattage (25 watts) for 30-60 min at the beginning of a gel run to allow some salt to separate from DNA, or (4) reducing the volume of irradiation samples to reduce the amount of salt that is dried down into the DNA

Increase concentration of both metal solution and DNA

Increase concentration of metal solution

Increase power of the light source or increase the irradiation time per sample

Increase amount of labeled DNA loaded per lane

Reduce concentration of metal complex in the solution or reduce the irradiation time have more specific considerations. In particular, experiments with $\left[\mathrm{Rh}(\mathrm{DIP})_{3}\right]^{3+}$ must control carefully for the superhelicity dependence of cleavage and whether the cleavage is single or double stranded. In addition, it must be carefully noted that in the absence of an unusual structure and at long irradiation times $\left[\mathrm{Rh}(\mathrm{DIP})_{3}\right]^{3+}$ does induce nonspecific oxidative damage at $5^{\prime}-\mathrm{GG}-3^{\prime}$ and $5^{\prime}-\mathrm{GA}-3^{\prime}$ sites. If this behavior is not adequately controlled, incorrect conclusions may be drawn from observed cleavage data.

In a related manner, when using $\left[\mathrm{Rh}(\mathrm{phi})_{2}(\mathrm{bpy})\right]^{3+}$ for DNA footprinting, the binding behavior of the metal complex must be considered to ensure that experimental results are meaningful. The concentration of the probe must be kept high to ensure nonspecific binding. Irradiation times must be kept short enough that there are not problems with excessive cleavage at these high loadings. Finally, one must also consider that the binding constant of rhodium phi intercalators for DNA is in the range of $10^{6}$ to $10^{8} \mathrm{M}^{-1}$, making it possible for them to displace weaker DNA-binding molecules from the polymer. A troubleshooting guide for photocleavage experiments is given in Table 6.2.1.

\section{Anticipated Results}

Using the numerous reagents and techniques described in these protocols, questions about the structure of an unknown nucleic acid sequence or lesion can be approached. In all
Chemical and Enzymatic Probes for Nucleic Acid Structure 
cases, rapid and relatively inexpensive techniques lead to identification of binding sites on the polymer of interest and direct information about the geometry and conformations of the molecule in solution. Because of the large variety of assays and probes included in this unit, it is more efficient to direct the reader to those original papers that include examples of experimental results than to reproduce examples here. Appropriate citations are included below (see Key References).

\section{Time Considerations}

Once the apparatus has been collected and is in place, most of the synthetic reactions described in this protocol can be completed within a single day. There are a few exceptions to this, including the synthesis of complexes involving 9,10-diaminophenanthrene. These procedures can require between a few days and a week, although the amount of hands-on time during these periods is minimal. Complex purification columns and enantiomer separation require an additional 1 day to 2 weeks of chromatography time. However, these time investments must be viewed with the knowledge that a single synthetic cycle will produce enough material for several hundred DNA structure experiments.

Once a given metal complex of interest is made and purified, the biological experiments proceed much more rapidly. DNA can be made and purified within 3 days, and labeled and isolated in another day. Irradiation reactions can be completed in 2 to $12 \mathrm{hr}$, depending on the number of samples involved. Electrophoresis and autoradiography on one set of samples requires an additional 1 to 2 days.

\section{Acknowledgments}

The work described here was supported by the NIH (GM33309) and performed by many able graduate students who are referenced as indicated. B.A.J. would also like to acknowledge the NSF for a predoctoral fellowship.

\section{Literature Cited}

Campisi, D., Morii, T., and Barton, J.K. 1994. Correlations of crystal structures of DNA oligonucleotides with enantioselective recognition by $\left[\mathrm{Rh}(\text { phen })_{2}(\mathrm{phi})\right]^{3+}$ : Probes of DNA propeller twisting in solution. Biochemistry 33:41304139.
Cartwright, P.S., Gillard, R.D., and Sillanpåå, E.R.J. 1987. Optically active coordination compounds-XLVI. Resolution of tris-diimmine compounds of chromium(III) using fac(+)tris[L-cysteinesulphinato(2-)SN]cobaltate (III). Polyhedron 6:105-110.

Chow, C.S. and Barton, J.K. 1992. Recognition of G-U mismatches by tris(4,7-diphenyl-1,10phenanthroline)rhodium(III). Biochemistry 31:5423-5429.

Chow, C.S., Behlen, L.S., Uhlenbeck, O.C., and Barton, J.K. 1992. Recognition of tertiary structure in tRNAs by $\left[\mathrm{Rh}(\mathrm{phen})_{2}(\mathrm{phi})\right]^{3+}$, a new reagent for RNA structure-function mapping. Biochemistry 31:972-982.

Dollimore, L.S. and Gillard, R.D., 1973. Optically active co-ordination compounds. Part XXXII. Potassium (+) tris-[L-cysteinesulphinato(2-)$\mathrm{SN}]$ cobaltate(III): A versatile agent for resolution of $3+$ species. J. Chem. Soc. Dalton Trans. (1973):934-940.

Gidney, P.M., Gillard, R.D., and Heaton, B.T. 1972. 1,10-Phenanthroline and 2,2'-bipyridyl complexes of rhodium(III). J. Chem. Soc. Dalton Trans. (1972):2621-2628.

Gillard, R.D., Osborn, J.A., and Wilkinson, G. 1965. Catalytic approaches to complex compounds of rhodium(III). J. Chem. Soc. Dalton Trans. (1965):1951-1965.

Greabe, V.C. and Hönisberger, F. 1900. Ueber die Oxydationsproducte des Chrysens. Ann. Chem. 311:257-265.

Hall, D.B., Holmlin, R.E., and Barton, J.K. 1996. Oxidative DNA damage through long range electron transfer. Nature 382:731-735.

Hartmann, B. and Lavery, R. 1996. DNA structural forms. Q. Rev. Biophys. 29:309-368.

Howells, R.D. and McCown, J.D. 1977. Trifluormethanesulfonic acid and derivatives. Chem. Rev. 77:69-92.

Huber, P.W., Morii, T., Mei, H.-Y., and Barton, J.K. 1991. Structural polymorphism in the major groove of a 5S RNA gene complements the zinc finger domains of transcription factor IIIA. Proc. Natl. Acad. Sci. U.S.A. 88:10801-10805.

Jackson, B.A. and Barton, J.K. 1997. Recognition of mismatches by a rhodium intercalator. $J$. Am. Chem. Soc. 199:12986-12987.

Jackson, B.A., Alekseyev, V.A., and Barton, J.K. 1999. A versatile recognition agent: Specific cleavage of a plasmid DNA at a single base mispair. Biochemistry 38:4655-4662.

Kirshenbaum, M.R., Tribolet, R., and Barton, J.K. 1988. $\left[\mathrm{Rh}(\mathrm{DIP})_{3}\right]^{3+}$ : A shape-selective metal complex which targets cruciforms. Nucl. Acids Res. 16:7943-7960.

Lee, I. and Barton, J.K. 1993. A distinct intronDNA structure in simian virus 40 T-antigen and adenovirus 2 E1A genes. Biochemistry 32:6121-6127. 
Lim, A.-C. and Barton, J.K. 1993. Chemical probing of tDNA ${ }^{\text {Phe }}$ with transition metal complexes: A structural comparison of RNA and DNA. Biochemistry 32:11029-11034.

Lim, A.-C. and Barton, J.K. 1997. Targeting the Tat-binding site of bovine immunodeficiency virus TAR RNA with a shape-selective rhodium complex. Bioorg. Med. Chem. 5:1131-1136.

Lin, C-T., Böttcher, W., Chou, M., Creutz, C., and Sutin, N. 1976. Mechanism of the quenching of the emission of substituted polypyridineruthenium(II) complexes by iron(III), chromium(III), and europium(III) ions. J. Am. Chem. Soc. 98:6536-6544.

Maxam, A. and Gilbert, W. 1980. Sequencing endlabeled DNA with base-specific chemical cleavages. Methods Enzymol. 65:499-560.

Mei, H.Y. and Barton, J.K. 1986. Chiral probe for A-form helices of DNA and RNA: Tris(tetramethylphenanthroline)ruthenium(II). J. Am. Chem. Soc. 108:7414-7416.

Mei, H.Y. and Barton, J.K. 1988. Tris(tetramethylphenanthroline)ruthenium(II): A chiral probe that cleaves A conformations. Proc. Natl. Acad. Sci. U.S.A. 85:1339-1343.

Müller, B.C., Raphael, A.L., and Barton, J.K. 1987. Evidence for altered DNA conformations in the simian virus genome: Site-specific DNA cleavage by the chiral complex $\Lambda$-tris(4,7-diphenyl1,10-phenanthroline)cobalt(III). Proc. Natl. Acad. Sci. U.S.A. 84:1764-1768.

Mürner, H., Jackson, B.A., and Barton, J.K. 1998. A versatile synthetic approach to rhodium(III) diimine metallointercalators: Condensation of $o$-quinones with coordinated cis-ammines. Inorg. Chem. 37:3007-3012.

Neenhold, H.R. and Rana, T.M. 1995. Major groove opening at the HIV-1 Tat-binding site of TAR RNA evidenced by a rhodium probe. Biochemistry 34:6303-6309.

Pyle, A.M., Long, E.C., and Barton, J.K. 1989. Shape-selective targeting of DNA by (phenanthrenequinone)rhodium(III) photocleaving agents. J. Am. Chem. Soc. 111:4520-4522.

Pyle, A.M., Chiang, M.Y., and Barton, J.K. 1990. Synthesis and characterization of physical, electronic, and photochemical aspects of 9,10-phenanthrenequinone diimine complexes of ruthenium(II) and rhodium(III). Inorg. Chem. 29:4487-4495.

Sitlani, A. and Barton, J.K. 1994. Sequence-specific recognition of DNA by phenathrenequinone diimine complexes of rhodium(III): Importance of steric and van der Waals interactions. Biochemistry 33:12100-12108.

Sitlani, A., Long, E.C., Pyle, A.M., and Barton, J.K. 1992. DNA photocleavage by phenanthrenequinone diimine complexes of rhodium(III): Shape selective recognition and reaction. J. Am. Chem. Soc. 114:2303-2312.
Uchida, K., Pyle, A.M., Morii, T., and Barton, J.K. 1989. High resolution footprinting of EcoRI and distamycin with $\left[\mathrm{Rh}(\mathrm{phi})_{2}(\mathrm{bpy})\right]^{3+}$, a new photofootprinting reagent. Nucl. Acids Res. 17:10259-10279.

Wilson, W.D., Tanious, F.A., Fernandez-Saiz, M., and Rigl, C.T. 1997. Evaluation of drug-nucleic acid interactions by thermal melting curves. In Methods in Molecular Biology, Vol. 90: DrugDNA Interaction Protocols (K.R. Fox, ed.) pp. 219-240. Humana Press, Totowa, N.J.

Yoshikawa, Y. and Yamasaki, K. 1979. Chromatographic resolution of metal complexes on Sephadex ion exchangers. Coord. Chem. Rev. 28:205-229.

\section{Key References}

Campisi et al., 1994. See above.

Examples of mapping the major and minor grooves of DNA with $[\text { Rh(phen })_{2}($ phi $\left.)\right]^{3+}$ and $\left[R u(T M P)_{3}\right]^{2+}$.

Chow et al., 1992. See above.

Examples of mapping RNA structure using rhodium probes.

Hartmann and Lavery, 1996. See above.

This is an excellent review of recent work in DNA structural determinations of $A-, B$-, and Z-form DNA, mismatches, abasic sites, and bulges. As such, it provides an excellent overview of many of the targets these metal complex probes can be used to elucidate.

Jackson and Barton, 1997. See above.

Examples of using $\left[R h(\text { bpy })_{2}(\text { chrysi })\right]^{3+}$ as a probe for DNA mismatches.

Kirshenbaum et al., 1988. See above.

Examples of site-selective cleavage of unusual structures in nucleic acids using $\left[R h(D I P)_{3}\right]^{3+}$.

Lim and Barton, 1997. See above.

Example of $\left[R u(\text { phen })_{3}\right]^{2+}$ used as a guanine-specific sequencing reagent for nucleic acids.

Uchida et al., 1989. See above.

Examples of footprinting both major groove- and minor groove-binding molecules using rhodium probes.

Contributed by Brian A. Jackson and

Jacqueline K. Barton

California Institute of Technology

Pasadena, California
Chemical and Enzymatic Probes for Nucleic Acid Structure 